Relações Sociais - Guilherme Augusto Bittencourt Corrêa

\title{
JUIZADOS ESPECIAIS CÍVEIS ESTADUAIS: ACESSO À JUSTIÇA?
}

\author{
Guilherme Augusto Bittencourt Corrêa*
}

\begin{abstract}
RESUMO
O presente trabalho trata de um tema de primordial importância, mas que não tem recebido a atenção devida e necessária da doutrina, qual seja o tema relativo aos Juizados Especiais Cíveis Estaduais. O estudo orienta-se para uma análise dos Juizados Especiais Cíveis Estaduais, órgãos previstos na Constituição da República de 1988 e instituídos pela Lei 9.099/95, com o objetivo de garantir o Direito Fundamental de Acesso à Justiça. Sabe-se atualmente que este direito por diversas vezes é violado e o estudo demonstra que mesmo nos Juizados Especiais, a violação deste direito é notada em variadas oportunidades. Portanto, o estudo analisa o funcionamento dos Juizados Especiais Cíveis Estaduais, sempre voltado para a análise da garantia constitucional do acesso à justiça. Por fim, busca demonstrar-se que em alguns momentos os Juizados Especiais Cíveis Estaduais não propiciam o almejado e prometido acesso à justiça.
\end{abstract}

Palavras-chave: Direito Fundamental; Acesso à Justiça; Juizados Especiais Cíveis Estaduais.

SUMÁRIO: 1 INTRODUÇÃO; 2 A QUESTÃo DO ACESSO À JUSTIÇA; 3 OS JUIZADOS ESPECIAIS CÍVEIS ESTADUAIS; 3.1 A LEI 9.099/1995; 3.2 PRINCÍPIOS DOS JUIZADOS ESPECIAIS; 3.3 PROCEDIMENTO DOS JUIZADOS ESPECIAIS CÍVEIS ESTADUAIS E UMA ANÁLISE CRÍTICA A PARTIR DA REALIDADE; 3.3.1 INÍCIO DO PROCEDIMENTO; 3.3 .2 TENTATIVA DE CONCILIAÇÃO DAS PARTES; 3.3.3 RESOLUÇÃO POR ARBITRAGEM; 3.3.4 AUDIÊNCIA DE INSTRUÇÃO E JULGAMENTO; 3.3.5 SENTENÇA E FASE RECURSAL; 3.3.6 AÇ̃̃o RESCISÓRIA; 4 CONCLUSÃO; REFERÊNCIAS; ANEXOS.

Mestrando em Direito das Relações Sociais - UFPR. E-mail:
guilhermecorrea1983@hotmail.com




\section{INTRODUÇÃO}

O presente trabalho tem por objetivo demonstrar o procedimento adotado nos Juizados Especiais Cíveis Estaduais, inclusive com análises da prática, voltado para uma visão à luz da questão do Acesso à Justiça.

O estudo é iniciado por uma breve síntese do conceito de acesso à justiça. Posteriormente, abordam-se os princípios que regem e norteiam o procedimento dos Juizados Especiais Cíveis Estaduais, seguindo-se de uma análise deste procedimento.

$\mathrm{Na}$ análise do procedimento, procura o autor entabular críticas fundadas em equívocos legislativos e em situações práticas ${ }^{1}$.

Por fim, o autor constata que em muitos casos, o objetivo de "Justiça de Fácil Acesso à Serviço da Comunidade"2 mostra-se meramente ilusório e frustrante a uma população que é extremamente carente de serviços prestados pelo Estado.

\section{A QUESTÃO DO ACESSO À JUSTIÇA ${ }^{3}$}

$\mathrm{Na}$ época em que vigia a autotutela os mais fortes venciam, a justiça era feita com as próprias mãos. Nesta época pode-se afirmar que não existia a jurisdição como se concebe atualmente, o Estado não possuía, como hoje ocorre, a autoridade ${ }^{4}$

${ }^{1}$ Ressalta-se que o autor realizou pesquisa junto aos Juizados Especiais Estaduais Cíveis (Central) de Curitiba-PR.

${ }^{2}$ Slogan afixado em vários locais no Juizado Especial Central de Curitiba/PR.

${ }^{3}$ Cappelletti e Garth disseram que: "o acesso à justiça pode, portanto, ser encarado como o requisito fundamental - o mais básico dos direitos humanos - de um sistema jurídico moderno e igualitário que pretenda garantir, e não apenas proclamar os direitos de todos". CAPPELLETTI, Mauro; GARTH. Bryant. Acesso à justiça. Trad. e rev. Ellen Gracie Northfleet. Porto Alegre: Fabris, 1988, p. 12.

4 Neste sentido: "Nas fases primitivas da civilização dos povos, inexistia um Estado suficientemente forte para superar os ímpetos individualistas dos homens e impor o direito acima da vontade dos particulares: por isso, não só inexistia um órgão estatal que, com soberania e autoridade, 
necessária para fazer valer sua vontade em detrimento da vontade dos particulares.

Mas, a partir do momento em que o Estado tomou para si o poder de dizer o direito, a partir do instante em que adquiriu o monopólio da Jurisdição, deve propiciar aos jurisdicionados tudo aquilo que conseguiriam se agissem por conta própria, ${ }^{5} \mathrm{em}$ sendo assim, o Estado tem o dever de objetivar e buscar um bom funcionamento do Poder Judiciário.

Antigamente, tinha-se a idéia de que o acesso à justiça era garantido aos cidadãos pelo simples fato de que a todos era garantido um direito de ir aos tribunais e apresentar suas razões, ora como autor, ora como réu.

Mas, parece evidente essa concepção do acesso à justiça era incompleta e mostrava-se como algo meramente formal. E que, não se mostra condizente com a realidade atual, que é a realidade de um Estado que busca o bem-estar social de seu povo.

Conforme se denota da análise da Constituição da República, esta regula o assunto no inciso XXXV, do artigo $5^{\circ}$, ao dizer que: "a lei não excluíra da apreciação do Poder Judiciário lesão ou ameaça a direito". ${ }^{6,7}$

garantisse o cumprimento do direito, como ainda não havia sequer as leis (normas gerais e abstratas impostas pelo Estado aos particulares). Assim, quem pretendesse alguma coisa que outrem o impedisse de obter haveria de, com sua própria força e na medida dela, tratar de conseguir, por si mesmo, a satisfação de sua pretensão. (...) A esse regime chama-se autotutela (ou autodefesa) e hoje, encarando-a do ponto de vista da cultura do século XX é fácil ver como era precária e aleatória, pois não garantia a justiça, mas a vitória do mais forte, mais astuto ou mais ousado sobre o mais fraco ou mais tímido". CINTRA, Antonio Carlos de Araújo; GRINOVER, Ada Pellegrini; DINAMARCO, Cândido Rangel. Teoria geral do processo. 20. ed. São Paulo: Malheiros, 2004, p. 21.

${ }^{5}$ Neste sentido: "Como foi proibida a autotutela, e o Estado tem o dever de conferir ao cidadão o mesmo resultado que se verificaria caso o agir privado (a ação de direito material) não estivesse proibido, é adequado e politicamente generoso o estudo do direito de ação como o direito à invocação do poder do Estado para que este realize a ação de direito material que ele mesmo proibiu, utilizando-se dos instrumentos processuais que devem estar adequadamente preordenados para atender ao direito material". MARINONI, Luiz Guilherme; ARENHART, Sérgio Cruz. Manual do processo de conhecimento. 3. ed. rev. atual. e ampl. São Paulo: RT, 2004, p. 68.

${ }^{6}$ Neste sentido: "Impende reconhecer que a garantia da ampla defesa e o correspectivo direito à tempestividade da tutela jurisdicional são valores constitucionalmente assegurados. É até curial que o direito de acesso à ordem jurídica justa, consagrado no art. 5, XXXV, da Constituição Federal, não exprima apenas que todos podem ir a juízo, mas, também, que todos têm direito à 
JUIZADOS ESPECIAIS CÍvEIS ESTADUAIS: ACESSO À JUSTIÇA?

Com a simples leitura deste dispositivo constitucional, nota-se que o constituinte teve o intuito de assegurar a todos, sem qualquer discriminação, o direito de ver a lesão ou a ameaça de lesão devidamente apreciada pelo Poder Judiciário. ${ }^{8,9}$

Para a melhor doutrina, ${ }^{10,11}$ o inciso XXXV, do artigo $5^{\circ}$ da Constituição, já assegurava o acesso à justiça em sentido amplo, ou seja, direito de a parte ter suas razões apreciadas pelo Judiciário, direito de participar do processo, direito a uma tutela efetiva, direito a uma jurisdição efetiva e tempestiva.

adequada tutela jurisdicional, ou melhor, 'à tutela jurisdicional efetiva, adequada e tempestiva'". CRUZ E TUCCI, José Rogério. Tempo e processo: uma análise empírica da fenomenologia processual (civil e penal). São Paulo: RT, 1997, p. 66.

7 "Ao Estado foi imposto pela Constituição Federal o dever de prestar assistência jurídica integral aos que comprovarem insuficiência de recursos, eis que no capítulo dos Direitos e Deveres Individuais e Coletivos estabelece que 'a lei não excluirá da apreciação do Poder Judiciário, lesão ou ameaça a direito." CUNHA, J.S. Fagundes. Recursos e impugnações nos Juizados Especiais Cíveis. 2. ed. Curitiba: Juruá, 1997, p. 32.

8 "Trata-se, o dispositivo, da consagração, em sede constitucional, do direito fundamental de ação, de acesso ao Poder Judiciário, sem peias, condicionamentos ou quejandos, conquista histórica que surgiu a partir do momento em que, estando proibida a autotutela privada, assumiu o Estado o monopólio da jurisdição. Ao criar um direito, estabelece-se o dever - que é do Estado: prestar jurisdição. Ação e jurisdição são institutos que nasceram um para o outro". DIDIER JR, Fredie. Notas sobre a garantia constitucional do acesso à justiça: o princípio do direito de ação ou da inafastabilidade do Poder Judiciário. Revista de Processo, São Paulo, n. 108, p. 23, out./dez. 2002.

${ }^{9}$ Neste sentido: "O princípio da inafastabilidade do controle jurisdicional, segundo o qual todos têm direito de ver apreciada pelo Poder Judiciário lesão ou ameaça de lesão a direito seu, não pode mais ser entendido pura e simplesmente como o direito da parte a uma sentença de mérito transitada em julgado (ainda que ineficaz, e somente depois de um processo moroso e caro...). O princípio da inafastabilidade do controle jurisdicional deve ser entendido, à luz dos valores dos nossos dias, em que se quer um processo de resultados, como inspirador da regra de que todos têm o direito a uma tutela efetiva e eficaz". WAMBIER, Teresa Arruda Alvim. apud BACELLAR, Roberto Portugal. Juizados especiais: a nova mediação paraprocessual. São Paulo: RT, 2003, p. 70.

10 "Todos esses direitos demonstram a extensão do direito de ação, que é muito mais do que o ato solitário de invocar a jurisdição ou do que um simples direito ao julgamento do mérito. A ação, diante dos seus desdobramentos concretos, constitui um complexo de posições jurídicas e técnicas processuais que objetivam a tutela jurisdicional efetiva, constituindo, em abstrato, o direito fundamental à tutela jurisdicional efetiva. (...) Como demonstrado, o art. $5^{\circ}, \mathrm{XXV}$, da Constituição Federal, embora afirme apenas que a lei não pode excluir da apreciação do Poder Judiciário lesão ou ameaça a direito, garante a tempestividade da tutela jurisdicional". MARINONI, Luiz Guilherme. Curso de processo civil. São Paulo: RT, 2006, p. 221.

11 "Como é sabido, o art. 5º XXXV, da Constituição da República, não só garante o direito ao acesso à justiça, mas igualmente o direito à efetividade e à tempestividade da tutela jurisdicional". MARINONI, Luiz Guilherme. Tutela antecipatória, julgamento antecipado e execução imediata da sentença. 3. ed. rev. e atual. São Paulo: RT, 1999, p. 160. 
Apesar da opinião acertada já apresentada, a EC no 45/2004 inseriu na Constituição, mais especificamente no artigo $5^{\circ}$, o inciso LXXVIII que estatui: "a todos, no âmbito judicial e administrativo, são assegurados a razoável duração do processo e os meios que garantam a celeridade da sua tramitação". Então, com a citada emenda constitucional não restam dúvidas de que um processo célere e com tempo razoável é sim garantia constitucional e, que deve ser assegurada por todos os poderes da República. ${ }^{12}$

Então, o "acesso à justiça" consiste numa gama de garantias, que podem ser expressas como o direito de: ir ao Judiciário e pleitear suas razões; receber tratamento adequado de auxiliares da justiça; receber tratamento adequado dos juízes; receber assistência jurídica ${ }^{13}$, inclusive antes da instauração do processo; ter o processo resolvido por meio de uma decisão justa, ${ }^{14}$ ( justiça com relação ao mérito, em tempo razoável $^{15,16}$ e efetiva $^{17}$ ).

${ }^{12}$ No mesmo sentido: "Esse direito fundamental, além de incidir sobre o Executivo e o Legislativo, incide sobre o Judiciário, obrigando-o a organizar adequadamente a distribuição da justiça, a equipar de modo efetivo os órgãos judiciários, a compreender e a adotar as técnicas processuais idealizadas para permitir a tempestividade da tutela jurisdicional, além de não poder praticar atos omissivos ou comissivos que retardem o processo de maneira injustificada". MARINONI. Curso de processo civil ..., p. 222.

13 "A assistência judiciária deve ser realizada como instrumento de acesso à ordem jurídica justa e não apenas de defesa técnica processual ou pré-processual." CUNHA, op. cit., p. 45.

${ }^{14}$ Neste sentido: "Como a mera solução da lide como resultado do processo, portanto não era mais suficiente, o processo passou a ser visto como o instrumento conferido à sociedade para a busca de 'justiça', passando a ser tocado pela filosofia do direito e sua imortal perseguição da aplicação do 'justo'. Seu escopo, dessa forma, estaria umbilicalmente ligado à 'justa composição da lide'". ZENKNER, Marcelo. Ministério Público e efetividade do processo civil. São Paulo: RT, 2006, p. 19.

${ }^{15}$ No mesmo sentido, diz que: "Destaca, nesse sentido, Teresa Sapiro Anselmo Vaz que o direito à jurisdição 'é indissociável do direito a uma tutela judicial efectiva que, por sua vez, pressupõe o direito a obter uma decisão em prazos razoáveis, sem dilações indevidas. Ou seja, a tutela judicial efectiva implica uma decisão num lapso de tempo razoável, o qual há de ser proporcional e adequado à complexidade do processo'". VAZ, Teresa Sapiro Anselmo apud CRUZ E TUCCI. Tempo e Processo ..., p. 66.

16 Neste sentido Cappelletti citando a Convenção Européia para Proteção dos Direitos Humanos e Liberdades Fundamentais diz que: "A Convenção Européia para Proteção dos Direitos Humanos e Liberdades Fundamentais reconhece explicitamente, no artigo $6^{\circ}$, parágrafo $1^{\circ}$ que a Justiça que não cumpre suas funções dentro de 'um prazo razoável' é, para muitas pessoas, uma Justiça inacessível". CAPPELLETTI; GARTH, op. cit., p. 20-21.

17 Assim, "Por outro prisma, a decisão judicial precisa ser passível de materialização, 
JUIZADOS ESPECIAIS CíveIS ESTADUAIS: ACESSO À JUSTIÇA?

Esclarecida a questão do Acesso à Justiça, passa-se à análise dos Juizados Especiais Cíveis Estaduais, órgão criado para garantir este direito a toda população.

\section{OS JUIZADOS ESPECIAIS CÍVEIS ESTADUAIS}

\subsection{A LEI 9.099/1995}

A Lei 9.099/95 dispõe sobre os Juizados Especiais Cíveis e Criminais. ${ }^{18}$ Esta lei revogou a Lei 7.244/84 que regulava os Juizados de Pequenas Causas.

Ao revogar a Lei 7.244/84, a Lei 9.099/95 modificou a nomenclatura, o que se considera de grande valia, já que modificou de Juizado de Pequenas Causas, para Juizado Especial, Cível e Criminal. Parece que tal mudança foi muito pertinente, pois a nomenclatura anterior já se mostrava discriminatória, uma vez, que deixava claro que tal juízo era para a discussão de "pequenas causas". Porém, a expressão "pequenas causas" é muito vaga e não exprime com clareza o que se busca definir.

Por isso, entende-se que a nomenclatura Juizados Especiais possui abrangência e alcance mais adequados, já que se tratam de causas que merecem ter rito

surtindo efeitos reais. O pronunciamento jurisdicional deve ser proferido e executado. Há para as partes um importante direito de fazer valer a sentença emanada do Judiciário, dando-lhe aplicações. De outra forma o provimento jurisdicional não teria qualquer força, sendo limitada ou nula a função de garantia de direitos e resolução de conflitos inerentes à atividade judicial. A eficácia da tutela judicial só pode ser aferida com base em aspectos concretos, de transformação da realidade. Daí que não se pode considerar eficaz em uma decisão que não foi executada, não tendo pois quase nenhum efeito prático. A efetividade da tutela pressupõe a garantia de que a decisão tomada pelo Poder Judiciário haverá de ser cumprida e respeitada. Há, em decorrência, um direito à execução da sentença. Este, como é óbvio, inclui o respeito dos demais poderes à decisão proferida pelo Juiz. Não será, portanto, possível que Executivo ou Legislativo venham a descumpri-la ou a ela oponham injustificados e ilegítimos embaraços". ARRUDA, Samuel Miranda. $O$ direito fundamental à razoável duração do processo. Brasília: Brasília Jurídica, 2006, p. 74.

\footnotetext{
${ }^{18}$ Ressalta-se que o presente estudo ater-se-á apenas à questão dos Juizados Especiais Cíveis.
} 
e tratamento especial, mas que apesar disso não se tratam de causas menores. ${ }^{19}$

A Lei 9.099/95, já em seu artigo $2^{\circ}$ dispõe que: "O processo orientar-se-á pelos critérios da oralidade, simplicidade, informalidade, economia processual e celeridade, buscando, sempre que possível, a conciliação ou a transação".

Parece claro que tal dispositivo procura acelerar o processo e simplificar a sua tramitação, além de enumerar os princípios que regem os Juizados Especiais.

\subsection{PRINCÍPIOS DOS JUIZADOS ESPECIAIS ${ }^{20}$}

Antes de iniciar a análise dos princípios próprios dos Juizados Especiais, importante destacar que em nenhum momento pode ser banida desta instituição a aplicação de demais princípios processuais e constitucionais, desde que, de acordo com a filosofia dos Juizados Especiais. ${ }^{21}$

Inicia-se a análise pelo princípio da oralidade ${ }^{22}$, que se refere ao fato de que os

19 "A mentalidade que informa os Juizados Especiais é precisamente esta: verificado que o conflito de menor complexidade tem certas particularidades próprias, é preciso dotar a jurisdição de instrumento capaz de lidar com esse litígio, sob pena de o conflito não encontrar na jurisdição estatal campo suficientemente adequado para ser resolvido". MARINONI; ARENHART, op. cit., p. 751.

20 "Trata-se dos princípios informadores dos Juizados Especiais, ou seja, daqueles que devem reger o trabalho intelectual do intérprete da lei, ao buscar o sentido e o alcance da norma jurídica. Estes princípios constituem a própria razão de ser dos Juizados Especiais". SILVA, Jorge Alberto Quadros de Carvalho. Lei dos juizados especiais cíveis anotada. 2. ed. rev. atual e ampl. São Paulo: Saraiva, 2001, p. 4.

21 "Por último acentuamos que todos os demais princípios fundamentais à orientação do universo processual civil e que estejam em sintonia com o espírito dos Juizados especiais, tais como o contraditório, ampla defesa, igualdade entre as partes, segurança jurídica, relação entre o pedido e o pronunciado etc., têm ampla e irrestrita aplicabilidade neste microssistema". FIGUEIRA JR, Joel Dias. Dos Juizados Especiais Cíveis. In: FIGUEIRA JR, Joel Dias; LOPES, Maurício Antônio Ribeiro. Comentários à Lei dos Juizados Especiais Cíveis e Criminais. São Paulo: RT, 1995. p. 46.

22 "Ainda sobre o princípio da oralidade, para concluir, poderíamos dizer que a sua acentuada adoção, nos moldes da Lei objeto destes comentários, apresenta ainda uma outra grande vantagem, que poderíamos chamar de 'ordem psicológica'; as partes têm a impressão de exercitar, elas mesmas, uma influência decisiva no deslinde da demanda, resultando, em contrapartida, no melhoramento da imagem do Judiciário perante os jurisdicionados". Ibidem, p. 52. 


\section{JUIZADOS ESPECIAIS CíveIS ESTADUAIS: ACESSO À JUSTIÇA?}

atos devem ser em regra orais, ou seja, somente o mínimo necessário e indispensável deve ser reduzido a termo ou ser escrito. ${ }^{23}$

Tal princípio mostra-se de grande valia já que além de simplificar o procedimento, põe as partes em contato mais próximo com o Juiz, levando, pelo menos em tese, a um julgamento mais justo e racional. ${ }^{24}$

O princípio da oralidade ainda pode levar a outras conclusões como: imediatidade, concentração e rapidez das decisões; e irrecorribilidade das interlocutórias. $^{25}$

Outro princípio de fundamental importância é o princípio da simplicidade. Na análise deste princípio, deve-se ter em mente que o procedimento nos Juizados Especiais deve ser simples, já que normalmente o espaço judiciário tende a inibir e constranger as pessoas que não estão acostumadas com esta situação de litígio.

O formalismo exagerado não pode ser aceito no ambiente dos Juizados Especiais. A questão formal deve apenas ficar restrita ao respeito e atendimento de direitos fundamentais das partes, como a ampla defesa e o contraditório.

Além de o procedimento ser simples, a linguagem empregada também deve ser, já que se deve mostrar acessível a todos e, uma linguagem rebuscada e com termos jurídicos inúteis acaba afastando o verdadeiro "público alvo" dos Juizados Especiais.

O terceiro princípio que vem descrito na lei é o da informalidade, preceituando

${ }^{23}$ No mesmo sentido: "A Lei n ${ }^{\circ}$ 9.099/95, reconhecendo a importância da proximidade com o Juiz, privilegiou a manifestação oral das partes litigantes, possibilitando-lhes com isso por exemplo, participar mais intensamente na formação do convencimento do julgador". HUTTER, Rudolf. Os princípios processuais no Juizado Especial Cível. São Paulo: Iglu, 2004, p. 84.

${ }^{24}$ Neste sentido: "O Juiz, quando em contato direto com as partes e com a produção de prova, pode formar uma convicção mais próxima da ideal a respeito dos fatos que dão conteúdo ao litígio." MARINONI. Tutela antecipatória ..., p. 218.

25 "O princípio da oralidade não quer dizer propriamente que todos os atos sejam praticados oralmente, mas supõe outros subprincípios que implicam uma decisão concentrada, imediata, rápida e irrecorrível suas interlocutórias". NOGUEIRA, Paulo Lúcio. Juizados especiais cíveis e criminais. São Paulo: Saraiva, 1996, p. 8. 
que os atos processuais não deverão necessariamente obedecer a formas específicas ${ }^{26}$, tendo-se os atos válidos à medida que atenderem à destinação que lhes foi dada. ${ }^{27,28}$

Um outro princípio trazido pela lei é o da economia processual. Ao tratar deste princípio alguns doutrinadores, de forma equivocada, dizem que este princípio prega o mínimo de gastos econômicos com o processo. Entende-se que tal conceito é equivocado, já que no Juizado Especial, pelo menos em primeira instância, não se exige o desembolso de valores. Pensa-se que a melhor explicação para referido princípio repousa no entendimento de outros autores, ${ }^{29,30}$ que afirmam que a economia processual consiste no fato de que os atos do processo devem ser em pequeno número, mas com a obtenção de muitos resultados, ou seja, poucos atos, mas muito resultado.

Por fim, tem-se o princípio da celeridade processual. Entende-se que este não é um princípio que pode ser respeitado sem que se atendam os demais, mostra-se como mera conseqüência do atendimento e garantia dos demais princípios já citados. Sendo assim, com a presença máxima de oralidade, simplicidade, informalidade e economia processual, o processo, ou procedimento tende a ser mais célere e, portanto, mais efetivo.

Analisados os princípios, passa-se à análise do procedimento da Lei 9.099/95.

26 "Na esfera do processo estatal, é injustificável nos tempos atuais, porque anacrônica, a visão de que a segurança de uma decisão judicial depende de rigorosa obediência à formalidade dos atos processuais. Assim, no Juizado Especial a formalidade é essencial na exata medida em que permita imprimir segurança e certeza jurídica à relação processual". HUTTER, op. cit., p. 91 .

${ }^{27}$ No mesmo sentido: "O que é imprescindível ao aplicador ou intérprete da lei processual é, antes de tudo, perquirir pela valoração normativa inserta em seu conteúdo. É averiguar, no caso concreto, se o ato alcançou sua meta ou serviu a sua finalidade. ZENKNER, op. cit., p. 29.

${ }^{28} \mathrm{Na}$ mesma linha de pensamento: "Não se deve no Juizado especial, repetir ato, ainda que nulo, que tenha atingido sua finalidade, desde que obedecidas as garantias fundamentais outorgadas às partes. MARINONI; ARENHART, op. cit., p. 746.

29 "É o que recomenda o denominado princípio da economia, o qual preconiza o máximo de resultado na atuação do direito com o mínimo emprego possível de atividades processuais." CINTRA; GRINOVER; DINAMARCO, op. cit., p. 73.

30 "É necessário minimizar a quantidade de atos processuais, evitando-se repetir atos já praticados, quando isso não seja indispensável para o legítimo desenvolvimento do processo. Não se deve no Juizado especial, repetir ato, ainda que nulo, que tenha atingido". MARINONI; ARENHART, op. cit., p. 746. 


\subsection{PROCEDIMENTO DOS JUIZADOS ESPECIAIS CÍVEIS ESTADUAIS E UMA ANÁLISE CRÍTICA A PARTIR DA REALIDADE}

\subsubsection{Início do Procedimento}

O procedimento inicia-se por meio do Reclamante ${ }^{31}$ que se dirige até o Juizado Especial Cível para fazer a sua reclamação e, esta é que dá início ao procedimento. Tal reclamação poderá ser escrita, ou oral (se oral será reduzida a termo), sem a obrigatoriedade de assistência por advogado, nos casos em que a demanda seja valorada em até vinte salários-mínimos. Nos casos superiores a vinte salários-mínimos até o limite de quarenta salários-mínimos, a assistência por advogado é obrigatória. ${ }^{32}$

Nos Juizados Especiais não se exigem os requisitos formais de uma petição inicial (art. 282 do CPC), nem poderia ser diferente, já que os princípios norteadores desta instituição pregam por uma simplicidade e informalidade e, a exigência de uma petição inicial nos termos do CPC certamente iria confrontar com estes princípios.

$\mathrm{Na}$ reclamação, é necessário conter apenas a qualificação das partes, seus endereços, o fato ocorrido de forma breve e clara e o pedido ${ }^{33}$.

${ }^{31}$ Nomenclatura mais adequada aos padrões do Juizado, já que visam a atender as demandas de pessoas de mais baixa classe social, portanto com a nomenclatura Reclamante e Reclamado, ao invés de Autor e Réu ou Requerente ou Requerido, as pessoas sentem-se mais à vontade e mais familiarizadas com o ambiente do processo.

${ }^{32}$ Note-se que, quando a lei fala em assistência por advogado, não se refere à representação por advogado, como acontece no procedimento do CPC. Nos Juizados Especiais Cíveis a parte deverá estar sempre presente, tanto na audiência de conciliação, como na de instrução e somente assistida por profissional habilitado, nunca representada por este, salvo em fase recursal, em que aí sim a representação acontece e é obrigatória.

33 Importante ressaltar que não há a necessidade de pedido imediato, como ocorre comumente nos juízos cíveis, que adotam o rito do CPC. Neste mesmo sentido: "O autor, notadamente nas causas de assistência facultativa, não tem qualquer obrigação de formular o pedido imediato; ele apenas relata os fatos, dirige um pedido de providências em face do réu, dizendo o que dele pretende (pedido mediato), e espera que o Juiz declare o direito de acordo com a sua pretensão. $\mathrm{O}$ Juiz terá de conhecer o caso e dar-lhe a conotação adequada (condenação, constituição, declaração, cominação)." BACELLAR, op. cit., p. 129 
Revista Eletrônica do CEJUR, Curitiba-PR, a. 2, v. 1, n. 3, ago./dez. 2008

Segundo a Lei 9.099/95, ao realizar a reclamação, antes mesmo da autuação e do registro, já deve ser agendada e informada ao reclamante a data da sessão conciliatória.

Mas o que ocorre na prática é muito diferente do que preceitua a lei. Antes de qualquer ato, ocorre sim o registro e autuação do processo devido à grande quantidade de processos. Além disso, em alguns casos, é solicitado ao reclamante que compareça alguns dias depois para saber a data em que foi marcada a sessão conciliatória.

Esta sessão conciliatória deverá ser marcada para os quinze dias subseqüentes à reclamação, sessão esta a ser conduzida por um conciliador, ${ }^{34}$ Juiz leigo $^{35,} 36$ ou togado.

Porém, o que vem ocorrendo é que a audiência de conciliação não é marcada no prazo de quinze dias conforme a lei, mas sim num prazo muito excedente a este. ${ }^{37}$

${ }^{34}$ Pessoa escolhida preferencialmente entre bacharéis em direito.

${ }^{35}$ Pessoa escolhida entre advogados com mais de cinco anos de experiência. Por esta razão, alguns autores entendem não ser correta a expressão Juiz leigo, já que para o senso comum, passa a idéia de que o Juiz leigo não conhece o direito. Um destes autores é Ricardo Cunha Chimenti que em sua obra usa a expressão Juiz Instrutor, ao invés de Juiz leigo. CHIMENTI, Ricardo Cunha. Teoria e prática dos juizados especiais cíveis. São Paulo: Saraiva, 1999, p. 43.

${ }^{36}$ A idéia de Juiz Leigo já era admitida no processo Italiano, lá havia colegiados de juízes leigos (populares) e de direito concorrendo com iguais poderes. Carnelutti defendia a existência de tais juízes, mas de maneira diferente, dizendo que: "Certamente, é necessária uma colaboração dos leigos com os técnicos do direito, tanto para resolver problemas técnicos distintos dos que se referem ao direito (para indagar, por exemplo, as causas do desmoronamento do edifício ou da morte de um homem), como também para provê-lo de um critério de justiça imediato e independente dos esquemas da lei, os quais freqüentemente se adaptam mal à natureza do caso; mas para esta necessidade, seria melhor sua assistência ao Juiz de direito no conceito de consultor, que a introdução do leigo no colégio judicial". CARNELUTTI, Francesco. Como se faz um processo. 3. ed. Trad. Hebe Caletti Marenco. Sorocaba: Minelli, 2005, p. 49-50.

${ }^{37}$ Em pesquisa realizada nos Juizados Especiais Cíveis de Curitiba foram examinados 102, sendo que em 6 deles não houve audiência de conciliação, pois o processo foi julgado improcedente de forma liminar e nos 96 restantes, o resultado da pesquisa foi o seguinte: em 2,08\% a audiência foi marcada dentro do prazo de 15 dias previsto em lei; em 2,08\% a audiência foi marcada num prazo de 16 a 30 dias; em 20,82\%, num prazo de 31 a 90 dias; em 26,05\%, num prazo de 61 a 90 dias; em $18,75 \%$, num prazo de 91 a 120 dias; em 7,30\%, num prazo de 121 a 150 dias e 22,92\% em prazos superiores a 150 dias. (dados da pesquisa em anexo) 


\section{JUIZADOS ESPECIAIS CíveIS ESTADUAIS: ACESSO À JUSTIÇA?}

\subsubsection{Tentativa de Conciliação das Partes}

Marcada a conciliação das partes, em data bastante longínqua, as partes dirigem-se até o Juizado para tentar a conciliação. Mas daí, já se observa o primeiro problema: o tempo de espera para a conciliação é tão longo que o descrédito na justiça aumenta.

Nessa audiência conciliatória, procura-se evitar a demanda, busca-se uma transação das partes e isto deve ser feito esclarecendo as partes sobre os riscos da demanda e das vantagens da conciliação. Importante esclarecer que, na grande maioria dos casos a reclamação é de pessoas humildes, com pouca instrução, contra grandes empresas e grupos econômicos e, estes representados por prepostos que, muitas vezes não têm a autorização momentânea para decidir pela possibilidade de conciliação, ou em outros casos não estão dispostas à realização de acordos, fazem com que a audiência conciliatória, transforme-se grande frustração à parte.

Aqui é pertinente uma reflexão, por que a lei 9.099/95 não propôs nenhuma sanção àqueles que não estão dispostos à conciliação e, mesmo assim não informam antecipadamente o juízo, fazendo com que a parte mais fraca da relação, que necessita muito dos valores discutidos em juízo, se enfraqueça ainda mais com a demora na resolução da lide? O fato de a parte mais fraca necessitar demasiadamente dos valores discutidos em juízo, faz com que muitas vezes ela se renda frente à demora do processo e ceda, realizando acordos que em nada são vantajosos, ${ }^{38}$ beneficiando normalmente a parte que não tem razão, mas tem condições de suportar a demora do processo.

Nessas situações parece ficar claro que os "litigantes habituais"39 acabam

${ }^{38}$ Neste sentido: "O principal problema da justiça civil, entretanto, era e ainda é o da morosidade dos processos. Todos sabem que os mais fracos ou pobres aceitam transacionar sobre os seus direitos em virtude da lentidão da justiça, abrindo mão de parcela da pretensão que provavelmente seria realizada, mas depois de muito tempo". MARINONI, Luiz Guilherme. Antecipação da tutela. 9. ed. rev. e ampl. São Paulo: RT, 2006, p. 22.

39 Definição de Cappelletti para aqueles que possuem acervo gigantesco de ações no 
agindo em favor da demora do processo, mostrando-se tal atitude como litigância de má-fé, que deve ser devidamente coibida e punida, pelas disposições do CPC, a fim de que tais atitudes não se repitam no processo e o tornem mais justo e efetivo. ${ }^{40}$

Aqui, entende-se que caberia por parte do Juiz a aplicação de sanções à parte que não pretende realizar qualquer tipo de acordo e que não informa o juízo antecipadamente, já que tal atitude em nada auxilia o processo, somente enfraquecendo a parte mais fraca e alongando demasiadamente o processo. ${ }^{41,42,43}$

O CPC trata da litigância de má-fé, por meio de conceitos abertos, que dependem muito da interpretação do magistrado e, no presente caso, uma interpretação constitucional da questão levaria à conclusão de que a parte que age de tal maneira age sim de má-fé e, que, portanto, deve sim ser punida.

Outra questão de destaque na lei, é que na conciliação o valor estipulado como limite de competência para os Juizados Especiais, poderá ser ultrapassado no caso de haver conciliação, como bem assevera o $3^{\circ}$, do artigo $3^{\circ}$ da referida lei. ${ }^{44}$

Judiciário. CAPPELLETTI; GARTH, op. cit., p. 25.

40 No mesmo sentido: "Se fosse o instituto da litigância de má-fé aplicado com mais freqüência pelos juízes, talvez não seriam tão constantes as violações ao princípio da lealdade processual e, certamente o processo seria mais efetivo". ZENKNER, op. cit., p. 62.

${ }^{41}$ No mesmo sentido: "Nessa linha, devemos admitir que a lentidão na prestação da tutela jurisdicional sempre acaba gerando benefícios à parte economicamente mais forte, em detrimento não somente da parte mais fraca (em regra, aqueles mais prejudicados pela violação de seus direitos), mas também do próprio Estado Democrático de Direito, eis que violada a igualdade de todos perante a lei". ZENKNER, op. cit., p. 37.

42 "A morosidade do Poder Judiciário é um benefício a quem não tem razão na relação processual, gerando toda sorte de injustiças. Ademais, a lentidão processual leva ao aumento dos custos econômicos advindos do acionamento e da manutenção do aparelho judicial". COSTA, Fábio Silva. Tutela antecipada: hermenêutica, acesso à justiça e princípio da efetividade processual. São Paulo: Juarez de Oliveira, 2000, p. 28

43 "No que se refere às partes, a intempestividade da tutela jurisdicional propicia indiscutível desigualdade social, pois a lentidão beneficia, no mais das vezes, a parte mais forte (rica), que pode esperar longos anos pela decisão. Um processo lento pode se tornar uma perigosa arma na mão dos mais ricos, os quais, em posse de bens e rendas alheias, podem oferecer, em troca da pronta cessão, apenas parcela do indevidamente apropriado". GAJARDONI, Fernando da Fonseca. O princípio constitucional da tutela jurisdicional sem dilações indevidas e o julgamento antecipadíssimo da lide. Revista de Processo, São Paulo, n. 141, p. 155, nov. 2006.

44 "Art. $3^{\circ}, \S 3^{\circ}$ : A opção pelo procedimento previsto nesta Lei importará em renúncia ao 


\section{JUIZADOS ESPECIAIS CíveIS ESTADUAIS: ACESSO À JUSTIÇA?}

Porém, o que poderia levar o réu a aceitar uma transação na qual poderia ser excedido o valor de quarenta salários-mínimos, uma vez que possui a opção de não fazer o acordo e mesmo perdendo a ação pagar valor com tal limite e num tempo futuro $?^{45}$ Parece que aqui, o legislador preocupou-se demais com a conciliação e fugiu um pouco da lógica e da realidade.

Voltando ao procedimento, após a sessão conciliatória, em havendo a conciliação, a mesma é reduzida a termo e se não forem constatados quaisquer vícios, o termo de conciliação é homologado pelo Juiz togado, ${ }^{46}$ encerrando-se o procedimento. O problema é que em muitos casos estes acordos só são realizados por fraqueza das partes, em momentos de desespero, não levando necessariamente à realização de transações favoráveis, não devendo ser tidos de forma geral como um substitutivo adequado e perfeito à resolução pela via jurisdicional. ${ }^{47}$

Mas, caso as partes não cheguem a um acordo, quem conduziu a sessão conciliatória deverá expor às partes que a demanda será instruída e julgada de forma judicial por um Juiz togado podendo este ser auxiliado por um Juiz leigo, ou haverá, se assim as partes decidirem, o julgamento da desavença por meio da arbitragem.

crédito excedente ao limite estabelecido neste artigo, excetuada a hipótese de conciliação".

${ }^{45}$ No mesmo sentido: "Fica o nosso alerta porque dificilmente o réu, mesmo que imbuído do mais alto espírito conciliatório, ao verificar que a sua negativa ao acordo proposto significará a renúncia do autor à importância excedente, em seu benefício, aceitará a proposta de conciliação. Aliás, nesse particular, este dispositivo em nada estimula a composição amigável". FIGUEIRA JR, op. cit., p. 136.

46 "A conciliação obtida pelo Juiz togado, pelo Juiz leigo e pelo Conciliador, sob a orientação do primeiro, deve ser reduzida a escrito. Quando realizada pelos dois últimos, será homologada pelo Juiz togado". SOARES, Nildomar da Silveira. Juizado Especial Cível: a justiça da era moderna. 3. ed. São Paulo: LTr, 1996, p. 49.

${ }^{47}$ No mesmo sentido: "o acordo não pode ser entendido como um substitutivo perfeito para a atuação dos mecanismos jurisdicionais e, nem mesmo como uma melhor maneira de se fazer justiça". FISS, Owen. Um novo processo civil: estudos norte-americanos sobre jurisdição, constituição e sociedade. São Paulo: RT, 2004, p. 9-10. 


\subsubsection{Resolução por Arbitragem}

Havendo a opção pela arbitragem, ${ }^{48}$ o árbitro será escolhido pelas partes e esse conduzirá a resolução da demanda e tomará a sua decisão, decisão está que deverá ser homologada pelo Juiz togado, que somente não a homologará no caso de existirem vícios formais na decisão. No tocante ao mérito da causa, em nada poderá interferir o magistrado.

Então, com o desejo das partes e determinação pelo conciliador $^{49}$ que a resolução da demanda dar-se-á por arbitragem, pode ser verificado mais um problema.

A oferta deste tipo de conciliação é raramente feita às partes, ${ }^{50}$ seja pelo desconhecimento dos possíveis árbitros, seja pelo desconhecimento do próprio procedimento.

A Lei $9.099 / 95$ ainda dispõe no $\S 2^{\circ}$, do artigo 24 , que o árbitro deverá ser escolhido dentre os Juizes leigos do Juizado especial. Aqui cabe uma análise. Pelo que dispõe a lei, os juízes leigos serão escolhidos dentre advogados com mais de cinco anos de experiência, portanto, a conclusão lógica é a de que os árbitros serão advogados com mais de cinco anos de experiência. ${ }^{51,52}$

48 "O que precisa ficar consignado em ata de audiência é a inexistência de conciliação e a opção das partes em instituírem o juízo arbitral, bem como a indicação comum de determinado Juiz leigo". FIGUEIRA JR, op. cit., p. 139.

${ }^{49} \mathrm{Na}$ esmagadora maioria de vezes, as conciliações são coordenadas por conciliadores e não por Juizes leigos ou togados, conforme se denota da pesquisa acima já referida, dos 102 processos pesquisados, em 38 não houve a audiência de conciliação, nos 64 em que houve tal audiência, no tocante à condução da audiência de conciliação o resultado foi: em $92,19 \%$ conduzidas por conciliadores; em 6,25\% por juízes leigos e em apenas 1,56\% conduzidas por juízes togados.

${ }^{50} \mathrm{Na}$ mesma pesquisa, dos 102 processos pesquisados em 38 deles não houve a audiência de conciliação, nos 64 em que houve tal audiência, o resultado foi o seguinte: em 96,87\% não houve a conciliação e não foi proposta às partes a decisão por arbitragem; em 3,13\% houve conciliação e em nenhum caso houve decisão por arbitragem, ou sequer a proposta deste tipo de procedimento às partes.

51 "Nos Juizados Estaduais, inviável o acordo, verificará o conciliador a possibilidade de instauração do juízo arbitral especial. O juízo arbitral especial é instaurado com a escolha do árbitro pelas partes. O árbitro, escolhido entre os juízes leigos dos Juizados Especiais, dirigirá o caso com ampla liberdade e apresentará sua decisão para homologação pelo Juiz togado. Ao Juiz togado caberá homologar o laudo arbitral, ou negar homologação se houver vícios formais. Não cabe ao Juiz togado 
JUIZADOS ESPECIAIS CÍvEIS ESTADUAIS: ACESSO À JUSTIÇA?

Ao analisar a questão da arbitragem, tem-se que esta surgiu como uma alternativa técnica de resolução de conflitos, diferente da judicial. Os defensores da arbitragem defendem-na pela melhor qualidade do julgamento, já que um terceiro que seja especialista no assunto objeto da lide é quem julgará e decidirá a desavença, diferentemente do que ocorre com um magistrado, que normalmente possui seus conhecimentos adstritos ao mundo jurídico.

Sendo assim, com a breve explicação acima desenhada fica complicada a defesa da arbitragem nos Juizados Especiais, que seria realizada por um advogado com mais de cinco anos de experiência, mostrando que o conhecimento técnico do árbitro seria o mesmo do Juiz, apenas o conhecimento jurídico. ${ }^{53}$ Este fato levanta outra

entrar no mérito da decisão, já que o árbitro é que foi escolhido e autorizado pelas partes a decidir (tese defendida pelo autor e aprovada no $1^{\circ}$ Simpósio Nacional de Pequenas Causas e Juizados Especiais, promovido pela Associação dos Magistrados Brasileiros, realizado em Curitiba, nos dias 4,5 e 6 de junho de 1992). Homologado o laudo, não cabe qualquer recurso, o que é justificado pelo fato de que nenhuma turma recursal, colégio ou tribunal está autorizado a modificar decisão de terceiro eleito pelas partes para dirimir a controvérsia". (BACELLAR, op. cit., p. 135-136). Neste ponto permite-se discordar do autor citado, pois entende-se que a escolha por ambas as partes do árbitro não é argumento válido para a irrecorribilidade da decisão. Pois ao pensar assim, tem-se como premissa que as decisões dos juízes padecem de desconfiança e carecem de imparcialidade, uma vez que admitem recurso. A recorribilidade deveria ter espaço na arbitragem, não porque a decisão não é confiável, mas porque é prolatada por um ser humano, que mesmo no papel de árbitro, está passível ao cometimento de erros e equívocos, que poderiam muito bem ser sanados pela revisão da decisão, como ocorre em alguns casos julgados pelo procedimento judicial.

${ }^{52}$ Questiona-se se a Lei 9.307/96, que dispõe sobre a arbitragem, teria revogado a parte da Lei 9.099/95 que trata do procedimento arbitral. Referida Lei de Arbitragem, no caput do artigo 13, dispõe que qualquer pessoa capaz poderá ser árbitro, diferentemente do que dispõe a Lei dos Juizados Especiais que afirma que os árbitros deverão ser escolhidos entre os juízes leigos. A tendência é entender que não houve a revogação acima suscitada, pois a Lei da Arbitragem trata da arbitragem em geral, portanto lei geral, já os artigos 24 e ss. da Lei dos Juizados Especiais tratam do procedimento arbitral nos Juizados Especiais, portanto lei especial, lei específica. Sendo assim, parece clara a antinomia, o conflito de normas: de um lado uma norma anterior e específica (Lei 9.099/95) e de outro uma norma posterior e geral (Lei 9.307/96). Aqui, tem-se um conflito de critérios (cronológico X da especialidade). Na resolução deste conflito, tem-se: "(...) esse conflito tem lugar quando uma norma anterior-especial é incompatível com uma norma posterior-geral. Tem-se conflito porque, aplicando o critério de especialidade, dá-se preponderância à primeira norma, aplicando o critério cronológico, dá-se prevalência à segunda. Também aqui foi transmitida uma regra geral, que soa assim: 'Lex posterior generalis non derogat priori speciali'. Com base nessa regra, o conflito entre critério da especialidade e critério cronológico deve ser resolvido em favor do primeiro: e lei geral sucessiva não tira do caminho a lei especial precedente. O que leva a uma posterior exceção ao princípio 'lex posterior derogat priori'." BOBBIO, Norberto. Teoria do ordenamento jurídico. 10. ed. Brasília: UnB, 1999, p.108

${ }^{53}$ No mesmo sentido: "Nada obstante, dependendo da natureza da demanda, poderia ser mais 
questão: que diferença teria a decisão tomada por um Juiz leigo, atuando como Juiz leigo, da decisão tomada, pelo mesmo Juiz leigo atuando como árbitro? Talvez a única e triste diferença seja a de que sua decisão como árbitro seja irrecorrível ${ }^{54}$ e sua decisão como Juiz leigo poderá ser revista pela Turma Recursal.

Além disso, outro obstáculo à instauração do procedimento arbitral nos Juizados Especiais, é o de que, como exigir dos jurisdicionados, na sua maioria pessoas humildes e de baixa instrução, que por meio de simples acesso aos quadros de juízes leigos dos Juizados Especiais, confiem nestes árbitros (juízes leigos) de forma a lhe darem o direito de decidir suas demandas sem uma garantia efetiva de isonomia e imparcialidade que o Estado, pelo menos em tese lhes proporciona? Parece que, no caso dos Juizados Especiais torna-se inviável e indefensável tal prática.

\subsubsection{Audiência de Instrução e Julgamento}

A audiência de instrução e julgamento ocorrerá quando as partes não optarem pela arbitragem. Esta audiência seguirá logo após a conciliação frustrada, salvo no caso de haver dificuldade de defesa para o reclamado, situação em que a audiência deverá ser marcada no período correspondente aos quinze dias subseqüentes.

Mas, observa-se que essa audiência é designada para data bastante longínqua, ${ }^{55}$ tornando ainda mais moroso o procedimento.

interessante aos contendores a indicação de um árbitro que tivesse conhecimento científico voltado para uma determinada área diversa do direito (p. ex.: bioquímico, engenheiro, médico, etc.). Essa talvez seja uma limitação criada pela Lei ao instituto da arbitragem nesse Juizados." FIGUEIRA JR, op. cit., p. 140.

54 "Ademais as decisões dos árbitros são irrecorríveis, o que por si só, já justifica a reserva dos litigantes nesta opção". Ibidem.

${ }^{55} \mathrm{Na}$ pesquisa já referida, nos 102 processos consultados, em 43 não houve audiência de instrução, nos 59 em que houve a audiência o resultado com relação ao prazo entres as audiências de conciliação e instrução foi o seguinte: em nenhum caso houve instrução logo em seguida da conciliação, como autoriza a lei; em apenas 1,7\% a audiência foi designada dentro do prazo dos 15 


\section{JUIZADOS ESPECIAIS CÍVEIS ESTADUAIS: ACESSO À JUSTIÇA?}

Na Audiência de Instrução e Julgamento o magistrado recebe a contestação ou exceção do réu, que poderá ser oral ou escrita, instrui o processo e, logo após já proclama a sua decisão. No caso de Audiência ser realizada por um Juiz leigo, este recebe a contestação, realiza a instrução da mesma forma que o Juiz togado e, por fim, emite um parecer, que é passado ao magistrado responsável para que este homologue o parecer, modifique-o ou, caso não se sinta seguro para julgamento, instrua novamente o processo.

Mas o que se nota na prática é que os Juízes Leigos acabam presidindo a Audiência de Instrução e Julgamento, ${ }^{56}$ mesmo não tendo jurisdição para tanto, ou seja, na prática o Juiz Leigo instrui o processo e elabora a sua decisão que quase sempre é homologada pelo Juiz Togado. ${ }^{57,} 58$

Outra questão pouco debatida na doutrina, mas que aqui tem lugar, é a da possibilidade de alteração da decisão tomada pelo Juiz leigo pelo Juiz togado. De acordo com a Lei dos Juizados Especiais ${ }^{59,}{ }^{60}$, o Juiz togado poderá modificar a

dias da lei; $13,56 \%$, o prazo foi entre 31 a 60 dias; em 18,64\%, o prazo foi entre 61 e 90 dias; em $3,4 \%$, o prazo foi entre 91 e 120 dias; em $15,25 \%$ o prazo foi entre 121 e 150 dias e, em $47,45 \%$, o prazo foi superior a 150 dias.

${ }^{56} \mathrm{Na}$ mesma pesquisa, dos 102 processos pesquisados em 47 deles não houve a audiência de instrução, nos 55 em que houve a audiência, o resultado foi o seguinte: em 87,27\% a audiência foi presidida por um Juiz leigo; e em apenas 12,73\% a audiência foi presidida por um Juiz togado.

$57 \mathrm{Na}$ pesquisa constatou-se que dos 102 feitos analisados, em 52,95\% o Juiz togado homologou o parecer do Juiz leigo; em 2,95\% o Juiz togado homologou parcialmente o parecer do Juiz leigo, alterando apenas dados numéricos, como índices de correção, juros; em 21,56\% o Juiz togado sentenciou o processo; em 7,84\% o autor desistiu da ação, antes ou durante a fase instrutória; em 4,9\% ainda não houve sentença; em 5,88\% o Juiz togado julgou improcedente liminarmente o processo, sem a necessidade de qualquer audiência; em 3,92\% o Juiz apenas homologou acordo realizado na conciliação ou depois dela; e em nenhum dos casos o Juiz togado proferiu outra sentença em substituição ao parecer do Juiz leigo, ou abriu novamente a instrução para proferir sua própria sentença.

${ }^{58} \mathrm{Na}$ mesma pesquisa, constatou-se que muitas sentenças homologadas pelos juízes togados padecem de erros e vícios primários, lançando a dúvida sobre se realmente os juízes togados tomam nota do que se passou no processo e de que forma foi proferia a decisão.

59 "Art. 40 - O Juiz leigo que tiver dirigido a instrução proferirá sua decisão e imediatamente a submeterá ao Juiz togado, que poderá homologá-la, proferir outra em substituição ou, antes de se manifestar, determinar a realização de atos probatórios indispensáveis".

$60 "$ (...) ainda que baseado na instrução probatória colhida pelo Juiz leigo, o Juiz togado pode julgar o mérito em oposição ao parecer ou 'projeto de decisão' do Juiz leigo. Embora seja 
decisão proferida pelo Juiz leigo, possuindo a faculdade de instruir novamente o processo, mas não é obrigado a esta nova instrução. Ou seja, o juiz, baseado na instrução de outra pessoa poderá modificar a decisão proferida.

Aqui, mostra-se clara a violação de importante princípio do processo, qual seja o da Identidade Física do Juiz, ${ }^{61}$ que consiste em garantir que o Juiz que presidiu a Audiência de Instrução profira o julgamento. Tal princípio possui grande importância, já que procura garantir o julgamento por aquele Juiz que esteve em contato direto com as partes e com as provas, sobretudo provas orais.

E, nos Juizados Especiais, esse princípio torna-se ainda mais importante, já que seu princípio norteador é o da oralidade ${ }^{62}$. Ainda devido à simplicidade das formas e das pessoas que acabam postulando sem a assistência de um advogado, o contato direto com as partes e testemunhas acaba sendo de fundamental importância para a prolação de uma sentença justa.

Outra questão que pode ser levantada: e, se o Juiz togado resolver instruir novamente o processo para tomar sua decisão? Será que não se teria um retrocesso no tocante à celeridade, compactuando com a morosidade do processo? Entende-se que sim. A idéia de que a atuação do Juiz leigo só vem a ajudar o Juiz togado é destruída quando o Juiz togado necessita de nova instrução para resolver a causa. Esta nova instrução e nova colheita de provas atrasam demasiadamente o procedimento, o que

fundamental o auxílio dos juízes leigos, o Juiz togado tem ampla liberdade de alterar, modificar ou substituir a decisão que não encontre amparo em convencimento e seu sentimento de justiça". BACELLAR, Roberto Portugal. Obra citada, p. 139.

${ }^{61}$ Art. 132, caput, do CPC: "O Juiz, titular ou substituto, concluir a audiência, julgará a lide, salvo se estiver convocado, licenciado, afastado por qualquer motivo, promovido ou aposentado, casos em que passará os autos a seu sucessor".

62 "Os dois primeiros princípios, o da oralidade e o da imediatidade entre o Juiz e as partes, ainda necessitam de um outro que lhes dá consistência e os torna efetivos. É o princípio segundo o qual o mesmo Juiz que haja presidido a instrução da causa deverá ser o Juiz da sentença. Ora, se a oralidade, como se viu, tem por fim capacitar o julgador para uma avaliação pessoal e direta não só do litígio, mas da forma como as partes procuraram prová-lo no processo, não teria sentido que o Juiz, a quem incumbisse prolatar a sentença, fosse outra pessoa, diversa daquela que tivera contato pessoal com a causa". SILVA, Ovídio A. Baptista da; GOMES, Fábio. Teoria geral do processo civil. 3. ed. rev. e atual. São Paulo: RT, 2002, p. 53. 
poderia ser evitado se desde o início do procedimento houvesse a atuação do Juiz togado, até porque, parece que aqueles "litigantes habituais" levam com mais seriedade e respeito, os procedimentos coordenados por um Juiz togado.

\subsubsection{Sentença e Fase Recursal}

Logo após a instrução da causa, o Juiz já deverá proferir a sentença. Todavia, o que vem ocorrendo é uma demora muito grande na prolação da sentença. Como normalmente os Juízes leigos é que coordenam a audiência de instrução, eles tardam em proferir a sua decisão e remetê-la ao Juiz togado, o que faz com que o prazo entre a audiência de instrução e a prolação de uma sentença mostre-se bastante alongado. ${ }^{63}$

Na sentença há uma peculiaridade nos Juizados Especiais. De acordo com o artigo 38 da Lei 9.099/95 é dispensado o relatório. Entende-se que esta dispensa contribui em muito para que decisões injustas sejam proferidas, já que com a ausência de relatório, não há como o Juiz togado se posicionar favoravelmente ou não ao parecer do Juiz leigo, a não ser que tome conhecimento de todo o processo, o que é inviável devido à grande quantidade de demandas nos Juizados Especiais. Pensa-se que, a inclusão de um relatório na sentença, em nada prejudicaria o atendimento dos princípios dos Juizados e em nada prejudicaria a celeridade processual, tão almejada no âmbito dos Juizados Especiais.

Voltando à questão da sentença, depois de ser proferida, caberão embargos de

${ }^{63}$ Dos 102 casos analisados, em 50 deles já houve audiência de instrução e sentença, na análise destes 50 casos, o resultado, considerando o prazo entre a instrução e a sentença foi o seguinte: em $4 \%$ a sentença foi dada na própria audiência; em $2 \%$ ela foi proferida dentro do prazo de 10 dias, prazo este fixado pelo CPC, utilizado aqui como sugestão de prazo; em outros $2 \%$ a sentença foi prolatada entre 11 e 30 dias; em 16\%, entre 31 e 60 dias; em 20\%, entre 61 e 90 dias; em 6\%, entre 91 e 120 dias; em outros 6\%, entre 121 a 150 dias e na maioria dos casos, em $44 \%$, a sentença foi prolatada em prazos superiores a 150 dias. 
Revista Eletrônica do CEJUR, Curitiba-PR, a. 2, v. 1, n. 3, ago./dez. 2008

declaração ${ }^{64,65}$ no prazo de cinco dias e, ainda o recurso inominado, recurso este com abrangência maior do que o recurso de apelação, ${ }^{66}$ devido à impossibilidade de recurso sobre as decisões interlocutórias. Sendo assim, todas as matérias que antes não foram discutidas (devido à ausência recursal), poderão, sem sofrer os efeitos da preclusão ${ }^{67}$, ser discutidas neste recurso. Este será julgado pela Turma Recursal (colegiado, instituído para este fim, formado por três juízes togados de primeiro grau de jurisdição). Lembrando que para a interposição de recurso, a representação por advogado torna-se obrigatória.

O Recurso Inominado deve ser interposto no prazo de dez dias, não possuindo efeito suspensivo ex lege, podendo o mesmo ser concedido pelo Juiz singular ou pela turma recursal em casos de urgência ou no caso de perigo de danos de difícil reparação.

${ }^{64}$ Importante destacar que de acordo com o artigo 50 da Lei 9.099/95, nos Juizados Especiais, a interposição de embargos de declaração suspende o prazo recursal e não interrompe, como dispõe o CPC. Algumas dúvidas são levantadas deve-se entender o citado dispositivo legal como suspensão ou interrupção. Entende-se que por ser lei posterior à reforma de 1994 do CPC e por ser lei específica ao procedimento dos Juizados, que prima pela celeridade - já que a devolução integral do prazo atrasaria ainda mais o procedimento -, que ocorre a suspensão do prazo, ou seja, o prazo para recurso, após o julgamento dos embargos de declaração, será apenas o tempo que faltava para o término do prazo e não o prazo integral como ocorre no CPC. Neste mesmo sentido, tem-se que: "Os embargos declaratórios são cabíveis no prazo de cinco dias, da ciência da decisão, por petição escrita ou oralmente. Sua interposição suspende o prazo para oferecimento de outros recursos, ao contrário do que se passa com os embargos de declaração no processo tradicional, que interrompem tais prazos". MARINONI; ARENHART, op. cit., p. 763.

65 "Em primeiro grau de jurisdição, o oferecimento tempestivo dos embargos ocasiona a suspensão do prazo para interposição do recurso de apelação. Há que se observar, e isso é deveras importante, diversamente do que dispõe o art. 538 do Código de Processo Civil, estamos diante de suspensão, e não de interrupção. Significa dizer que os dias já decorridos não serão recobrados, ou, em outras palavras, o prazo não recomeça a fluir ex novo, em toda a sua inteireza. Para a interposição do recurso principal restam os dias que lhe sobejarem". FIGUEIRA JR, op. cit., p. 207.

66 "Por regra geral, o recurso não está sujeito a hipóteses que o motivem ou justifiquem porque sua cognitio se estende a qualquer tipo de erro ou injustiça da sentença a quo; assim como a qualquer tipo de irregularidade que possa invalidar essa mesma instância a quo. Desse modo o recurso possui um conteúdo muito mais amplo e genérico que qualquer outro tipo de recurso previsto no Código de Processo Civil, podendo denunciar tantos erros in iudicando como os vícios in procedendo da instância processual a quo". CUNHA, op. cit., p. 69-70.

67 "Deve ser enfatizado que não haverá preclusão das decisões interlocutórias. Preclusão, recordemos, é a extinção de certos direitos que não foram exercidos ou alegados dentro do prazo legal, ou prefixado". SOARES, op. cit., p. 73. 


\section{JUIZADOS ESPECIAIS CíveIS ESTADUAIS: ACESSO À JUSTIÇA?}

Outra questão a se destacar é que para a interposição do recurso inominado, diferentemente do que ocorre na fase inicial, exige-se o recolhimento de custas, inclusive das custas antes dispensadas, custas estas que só serão dispensadas no caso de beneficiários de assistência judiciária gratuita. Peculiaridade interessante aqui e, que se considera como um grande avanço é a possibilidade de o recolhimento das custas ser feito no prazo de quarenta e oito horas ${ }^{68}$ após a interposição do recurso, o que faz com que, os impertinentes conhecidos dos bancos não dificultem ainda mais o acesso recursal.

Aqui é pertinente uma crítica. Por que exigir o pagamento de custas para a interposição do recurso inominado, inclusive das custas antes dispensadas? Muitos vão dizer que aos necessitados é oferecida a assistência judiciária gratuita. Realmente há esta possibilidade, mas o desconhecimento deste direito é grande e, não pode ser simplesmente desconsiderado, pois é explícita a divulgação de que os Juizados Especiais propiciam uma justiça gratuita e sem custos. Sendo assim, as pessoas quando ingressam com a sua reclamação e não necessitam despender quaisquer valores, equivocadamente, mas de forma totalmente compreensível, entendem que já asseguraram o direito de pleitearem seus direitos de forma gratuita.

Então parece claro, mais um inconveniente legislativo de difícil compreensão. Poderia se defender que as custas inibem o grande mau que é a proliferação dos recursos, o que leva a uma morosidade processual. Mas não se pode cair na armadilha de que os Juizados devem propiciar apenas decisões céleres, pois além de céleres devem ser justas e corretas. ${ }^{69}$ Explicar a questão da cobrança de custas com o simples argumento de que com a necessidade do preparo para recorrer, as pessoas ficam inibidas a interpor recursos meramente protelatórios, é uma grande falácia.

\footnotetext{
68 "Deverá o apelante atentar, porém, que o prazo concedido não é de dois dias, mas de quarenta e oito horas, procedendo-se à contagem, portanto, de minuto a minuto". FIGUEIRA JR, op. cit., p. 195.

69 "O reexame da causa em um mesmo grau de jurisdição objetivou propiciar, nos Juizados Especiais, um maior acesso à justiça. Não basta só o acesso à decisão em primeira instância. A facilitação da procura de direitos junto aos Juizados Especiais deve englobar o acesso às turmas recursais" BACELLAR, op. cit., p. 139.
} 
$\mathrm{Na}$ grande maioria dos casos, os autores de demandas nos Juizados Especiais são pessoas sem condições financeiras para arcar com o custo do processo ou com honorários de advogado. Partindo-se desta premissa, tem-se que as pessoas preferem já ter as suas causas decididas em primeira instância, já que resolverão mais rapidamente as demandas, o que lhes é muito benéfico, pois o ambiente do Judiciário não lhes faz bem $^{70}$ e, também porque não precisarão arcar com o preparo recursal e nem com a contratação de profissional da advocacia, levando a crer que estes demandantes eventuais, somente recorrerão quando realmente entenderem injustas as decisões.

Com isso, tem-se que a esmagadora maioria dos recursos inominados é interposta por grandes empresas que possuem departamentos jurídicos, advogados qualificados e condições de arcarem com os custos da fase recursal.

Por isso, conclui-se que mesmo com a exigência de custas na fase recursal, esses "litigantes habituais" recorrem indiscriminadamente, na maioria dos casos apenas para protelar o processo e enfraquecer ainda mais a parte que em muitas vezes tem razão, ${ }^{71}$ mas que não possui condições de arcar com a demora processual.

Então, pode-se dizer que a exclusão de custas nos Juizados Especiais, inclusive na fase recursal, não aumentaria a morosidade processual desmotivada e nem faria com que houvesse uma "enxurrada" de recursos desarrazoados, pois atualmente os "recorrentes habituais"72 utilizam-se dos recursos sempre que possível, pouco importando a existência das custas.

${ }^{70}$ No mesmo sentido: "o cidadão comum não se sente à vontade nos recintos tradicionais em que se exerce a função jurisdicional: tudo aí se lhe afigura estranho, misterioso, e não é de admitir que lhe inspire mais desconfiança e temor do que tranqüilidade". BARBOSA MOREIRA, José Carlos apud ZENKNER, op. cit., p. 30.

${ }^{71} \mathrm{Na}$ mesma linha: "Como se isso já não fosse o bastante, a demora na obtenção da tutela sempre beneficia ao réu que não tem razão. A manutenção do direito demandado, no longo do decorrer do processo, em poder daquele que está errado (em detrimento do verdadeiro tutelado pelo direito), representa, seguramente, o maior contrasenso do sistema. O réu que não tem razão lucra com a demora, pois além de permanecer indevidamente em poder da coisa alheia, colhe os frutos". GAJARDONI, op. cit., p.155.

72 Expressão, análoga à criada por Cappelletti e já citada acima, utilizada pelo autor denominando as partes que recorrem de maneira indiscriminada. 


\section{JUIZADOS ESPECIAIS CíveIS ESTADUAIS: ACESSO À JUSTIÇA?}

Portanto, a exclusão total das custas no âmbito dos Juizados Especiais apenas garantiria o atendimento do princípio da paridade de armas, ou seja, da igualdade de forças dentro de uma demanda judicial, fazendo com que ambas as partes litigassem em igualdade de condições, sagrando-se vencedora aquela que detenha o direito ao seu lado e não aquela com melhores condições econômicas. ${ }^{73}$

Da decisão proferida pela turma recursal é possível a interposição de Embargos de Declaração ou de Recurso Extraordinário (artigo 102, II da CR/88).

O Recurso Especial não é cabível na esfera dos Juizados Especiais, já que o dispositivo Constitucional (artigo 105, III) prevê a interposição deste recurso nos casos em que as causas forem julgadas em única ou última instância, pelos Tribunais Regionais Federais ou pelos Tribunais dos Estados, do Distrito Federal e Territórios e, como nos Juizados Especiais, o recurso é julgado pelas Turmas Recursais e não por um Tribunal, ${ }^{74}$ não se entende possível a presença desta espécie recursal.

E, para firmar esse entendimento, o Superior Tribunal de Justiça, editou a Súmula 203 que estatui: "Não cabe recurso especial contra decisão proferida por órgão de segundo grau dos Juizados Especiais".

Tal entendimento pode gerar danos enormes às partes e à justiça como um todo. Imagine-se o caso de um julgamento realizado por uma Turma Recursal que viole literal dispositivo legal ou que interprete de forma diversa a outro Tribunal ou Turma Recursal determinado dispositivo de lei federal, em tal situação nada poder ser

\footnotetext{
${ }^{73}$ Neste sentido, a sábia lição de Mauro Cappelletti: "A efetividade perfeita, no contexto de um dado direito substantivo, poderia ser expressa como a completa 'igualdade de armas' - a garantia de que a conclusão final depende apenas dos méritos jurídicos relativos das partes antagônicas, sem relação com diferenças que sejam estranhas ao Direito e que, no entanto, afetam a afirmação e reivindicação dos direito". CAPPELLETTI; GARTH, op. cit., p. 15

${ }^{74}$ Mesmo contrário à idéia da possibilidade de interposição de Recurso Especial no âmbito dos Juizados Especiais, Joel Dias Figueira Jr. entende que o argumento de que não é possível pelo motivo da turma recursal não ser um tribunal, não deve vigorar: "Os Colégios, para fins de conhecimento dos diversos meios de impugnação, e, dentro das limitações estabelecidas pelo microssistema, equiparam-se em suas funções aos Tribunais de Alçada ou de Justiça, sendo possível se chegar a este resultado exegético através de interpretação analógica e extensiva do inciso III do art. 15 da Lei Maior. Em outras palavras, não são tribunais, mas equiparam-se a eles, na qualidade de Turmas de segundo grau." FIGUEIRA JR, op. cit., p. 235
} 
feito, parece claro que tal situação é absurda em um estado Democrático de Direito.

Pode-se afirmar que a situação acima desenhada soa como fator de retrocesso, já que um julgamento realizado ao arrepio da lei restará inatacado devido a um dispositivo constitucional que, parece padecer de erro material. Qual seria a razão do constituinte em oferecer às partes a interposição do Recurso Extraordinário e negar tal oferta no tocante ao Recurso Especial $?^{75}$ Parece que nenhuma. Não há razão para referida negação, por isso a interpretação do referido dispositivo Constitucional deveria ser feita no sentido de incluir a possibilidade de interposição de Recurso Especial das decisões proferidas pelas Turmas Recursais dos Juizados, ${ }^{76}$ ainda mais

${ }^{75}$ Neste sentido, o voto vencedor do Ministro Bueno de Souza no julgamento do RMS 2330: "Mas o que importa, ao meu ver, data vênia, é consignar que, se é admissível recurso extraordinário contra decisão proferida em pequenas causas, isto demonstra que esse Juizado não pode pairar acima da Constituição. O mesmo entendimento há de conduzir à admissão do recurso especial, porque o Juizado não pode pairar acima da lei federal. Assim, não há senão admitir que o Juizado possa, em tese praticar lesão de direito certo e líquido mediante abuso de poder ou pela prática de ilegalidade, enquanto, por outro lado, vedada fica a possibilidade de reexame dessa decisão. Reporto-me ainda ao voto que proferi, (...) no julgamento do RESP 21.664-7-MS, para reiterar minhas pessoais inquietações ante o critério que vem predominando e que parece redundar na ereção do Juízo de Pequenas Causas como fonte autônoma de direito (fonte formal e, o que é mais grave, fonte material de direito), podendo ser este discrepante do direito, ao qual todos nos sujeitamos, salvo então, o juízo soberano e incontestável desses pequenos tribunais". (RMS 2330/SP - Relator Ministro Bueno de Souza - Quarta Turma - Julgado em 16/03/93 - DJ de 25/10/1993 p. 22495) Disponível na Internet via www.stj.gov.br. [on line]. Acessado em 11/07/2007 às 09:00 h.

76 Neste sentido, o voto vencido do respeitado processualista, Ministro Athos Gusmão Carneiro no julgamento do REsp 23.866: "O eminente Des. Vice-Presidente do Pretório a quo trouxe à colação referência doutrinária de minha autoria, pelo não cabimento do apelo especial, (...). Meditando melhor e mais detidamente sobre a matéria, encontrei todavia relevantes fundamentos em contrário a esta nossa inicial manifestação feita em plano doutrinário. Sob a visão estritamente jurídica, as Turmas ou Câmaras Recursais não serão 'tribunais' do ponto de vista administrativo, pois não desfrutam das prerrogativas do art. 96 da CF, e não são assistidas necessariamente por Secretarias próprias, podendo valer-se do pessoal de apoio dos próprios Juizados Especiais de primeiro grau, tendo conforme previsto na lei estadual. Já sob o aspecto funcional, que pode ser considerado o realmente fundamental, as Turmas Recursais, embora integradas por juízes de primeiro grau, desempenham função absolutamente idêntica a dos Tribunais de Justiça ou dos Tribunais de Alçada: apreciam as causas em segundo grau de jurisdição e em colegiado, e suas decisões adquirem a mesma eficácia de coisa julgada formal e material. A demanda indenizatória, de que cuidou o processo ora em apreciação, foi julgada pela Turma Recursal assim como poderia ter sido julgada por Câmara do TJMS, anteriormente à criação, naquela Unidade da Federação, dos Juizados Especiais, que tanto vêm contribuindo para aproximar a Justiça dos Jurisdicionados. Perfeitamente razoável, portanto, entender que do ponto de vista funcional as Turmas Recursais, atuando como multiplicados pequenos 'Tribunais de Alçada', se me permitem a expressão, são em tudo equiparáveis a um Tribunal do Estado, são tribunais dos Estados, cabendo pois admitir o recurso especial de suas decisões, nos casos previstos nos incisos do artigo 105, III da Lei Maior. (...) Além disso, e eis o argumento de máxima 
pensando que a Constituição da República deve ser interpretada de forma a garantir direitos e não de excluí-los e, no presente caso, ao permitir a interposição do Recurso Especial, estar-se-ia garantindo um direito de acesso à justiça com a proteção do "devido processo legal", ${ }^{77}$ que deve ser entendido como propiciador de uma decisão justa.

Se assim for mantida a interpretação do dispositivo constitucional em comento, com a impossibilidade de interposição do Recurso Especial, estará sendo garantindo o "Acesso à Injustiça" já que permitiria a eficácia e validade de uma decisão contrária à lei, situação totalmente avessa e descabida em um Estado Democrático de Direito.

\subsubsection{Ação Rescisória}

Outra questão peculiar dos Juizados Especiais é a da impossibilidade do

relevância em país federativo em que o direito material civil, penal e comercial é o mesmo para todo o território nacional, não parece cabível deixar fora do controle de legalidade uma ampla gama de leis federais. E até pior: a matéria v.g. da importante ação adjudicatória, com toda uma série de variadas questões jurídicas controversas, ficará sujeita ao controle de legalidade relativamente aos arestos proferidos nos Estados onde tais causas estejam sujeitas aos Tribunais de Justiça ou de Alçada, mas alheias a tal controle nos Estados, como por exemplo em Santa Catarina, em que estas demandas são ajuizadas perante os Juizados Especiais? E o que dizer da ação de despejo, que a Lei 8.245/91, art. 80, faculta sejam consideradas 'causas cíveis de menor complexidade'? Em alguns Estados, este STJ poderá corrigir as ofensas à lei federal, mas noutros não? Se divergirem, a respeito da Lei do Inquilinato, dois Tribunais estaduais, caberá ao STJ a tarefa uniformizadora, mas se o dissídio ocorrer entre Turmas Recursais, será no plano infraconstitucional, totalmente irremediável? Devo portanto reconsiderar meu anterior entendimento sobre o tema, e declarar, em princípio, como admissível o recurso especial contra decisões das Turmas Recursais dos Juizados Especiais, quando fundamente invocada contrariedade à lei federal, ou quiçá até a jurisprudência sumulada desta Corte". (REsp 23866/SC - Rel. Min. Athos Gusmão Carneiro - 4a Turma - Julgamento 13/04/1993 - DJ de 25/10/1993 p. 22498) www.stj.gov.br. [on line] Acessado em 11/07/2007 às 09:00 h.

${ }^{77}$ Neste sentido: "Inspirado nos valores éticos consagrados pela Constituição, a idéia de devido processo legal veicula a noção de instrumento apto a proporcionar o verdadeiro acesso à justiça, ou seja, a de um processo aparelhado para assegurar a 'obtenção dos resultados justos que dele é lícito esperar". THEODORO JÚNIOR, Humberto. Boa-fé e processo: papel do juiz. In: MARINONI, Luiz Guilherme (coord.). Estudos de direito processual civil, homenagem ao Professor Egas Dirceu Moniz de Aragão. São Paulo: RT, 2005. p. 641. 
ingresso da Ação Rescisória ${ }^{78}$, pois se entende que esta possibilidade poderia alongar o rito e contrariaria os princípios informadores dos Juizados.

Aqui, mais uma vez um dispositivo que se mostra contrário ao alcance da justiça, já que a Ação Rescisória existe para a rescisão de sentenças eivadas de vícios que contaminam a decisão. Quer parecer que o legislador proibiu a possibilidade de Ação Rescisória pelo fato de que o procedimento no Juizado Especial deve ser célere e não pode abrir a possibilidade de nova discussão. Realmente, a preocupação do legislador foi pertinente, mas além de célere o processo deve ser justo e justiça no processo consiste também em uma decisão justa. Portanto, entende-se que a impossibilidade de Ação Rescisória ${ }^{79}$ causa mais danos do que benefícios, já que uma decisão célere e injusta mostra-se como um retrocesso ao alcance do Acesso à Justiça.

Deve haver distinção entre celeridade processual (sempre cuidando com a segurança jurídica) e tempo necessário (o que leva à segurança jurídica) à realização de certos atos. ${ }^{80} \mathrm{E}$, o direito à Ação Rescisória mostra-se como um direito que visa, sobretudo, garantir justiça às decisões e que, portanto, não pode ser visto como fator de morosidade, ou fator contrário à celeridade, mas sim como um fator necessário do processo e que, portanto, tem seu prazo necessário, que deve sim ser preservado, prazo

${ }^{78}$ Art. 59: "Não se admitirá ação rescisória nas causas sujeitas ao procedimento instituído por esta Lei".

${ }^{79}$ Em defesa da possibilidade da Ação Rescisória no âmbito dos Juizados Especiais: "Francamente, não encontramos razões plausíveis para excluir a ação rescisória do elenco dos meios de impugnação contra as decisões proferidas nestes Juizados, porquanto não nos parece razoável admitir (seria até ingenuidade) que os juízes de primeiro grau ou os Colégios Recursais não incidirão jamais em qualquer das hipóteses figuradas no art. 485 do CPC". MARINONI.. Tutela antecipatória ..., p. 139.

${ }^{80}$ No mesmo sentido: "não se pode olvidar, nesse particular, a existência de dois postulados que, em princípio, são opostos: o da segurança jurídica, exigindo, como já salientado, um lapso temporal razoável para a tramitação do processo (tempo fisiológico), e o da efetividade deste, reclamando que o momento da decisão final não se procrastine mais do que o necessário (tempo patológico). Obtendo-se um equilíbrio desses dois regramentos - segurança/celeridade -, emergirão as melhores condições para garantir a justiça no caso concreto, sem que, assim haja diminuição no grau de efetividade da tutela jurisdicional." CRUZ E TUCCI, José Rogério. Garantias constitucionais do processo civil. São Paulo: RT, 1999, p. 237. 


\section{JUIZADOS ESPECIAIS CÍVEIS ESTADUAIS: ACESSO À JUSTIÇA?}

este chamado de "tempo razoável" 81.

Feitas as análises acima alinhadas, foi demonstrado que os Juizados Especiais Cíveis, com seu procedimento sumaríssimo ${ }^{82}$, padecem de muitos problemas, sejam legislativos, sejam de operacionalização, mostrando-se muitas vezes ineficazes no atendimento do objetivo de Acesso à Justiça, objetivo este pregado quando da instituição destes órgãos e, por algumas pessoas, tido como cumprido por estes órgãos.

\section{CONCLUSÃO}

Pode-se concluir do presente trabalho que em muitos casos a Justiça não é proporcionada no âmbito dos Juizados Especiais, havendo, portanto, a violação da garantia de Acesso à Justiça. Algumas conclusões pontuais podem ser agora elencadas: a) a lei falha ao não prever qualquer sanção à parte que não tem interesse em realizar acordo na sessão conciliatória e não informa antecipadamente o juízo; b) a lei possui dispositivo de aplicação duvidosa, quando prevê a possibilidade de valor superior ao "teto" dos Juizados no caso de conciliação; c) a previsão de arbitragem pela lei não oferece quaisquer garantias às partes, tornando o procedimento quase que utópico; d) a lei autoriza expressamente a violação do princípio da identidade física do juiz, princípio de grande importância na esfera dos Juizados Especiais; e) a dispensa do relatório nas sentenças mostra-se despropositada; f) a cobrança de custas na fase recursal é incoerente e; g) a impossibilidade de Recurso Especial e de Ação Rescisória certamente colabora com a injustiça das decisões.

81 "O tempo razoável seria, então uma junção entre as idéias de celeridade e de tempo necessário. (...) Na Itália, há quem distinga o prazo razoável do prazo côngruo. Este último seria precisamente o adequado 'ao exercício dos poderes processuais da parte', enquanto o primeiro voltarse-ia à preservação de uma duração processual razoável globalmente considerada". ARRUDA, op. cit., p. 215 .

82 "Note-se que o procedimento estabelecido na Lei n. 9.099/95 não é sumário, mas sim sumaríssimo - (...)- isto é, um rito extremamente sumário, cujas características são a rapidez, simplicidade, informalidade e economia processual". FIGUEIRA JR, op. cit., p. 53. 
Portanto, conclui-se que são necessárias mudanças e que o Acesso à Justiça almejado e objetivado por vezes aparece como mera utopia ou sonho. As mudanças devem dirigir-se aos legisladores, doutrinadores e as pessoas que operacionalizam os Juizados Especiais. No Brasil sabe-se que o Poder Legislativo passa por grande crise e sofre com escândalos de corrupção, portanto depender deste Poder para alguma mudança é quase uma utopia. A doutrina aos poucos vem alertando para os problemas e apresentando algumas soluções. Mas, entende-se mesmo que quem pode contribuir para esta mudança de forma radical e eficiente são os operadores desse microssistema, que é de fundamental importância para toda a sociedade brasileira.

\section{REFERÊNCIAS}

ARRUDA, Samuel Miranda. O direito fundamental à razoável duração do processo. Brasília: Brasília Jurídica, 2006.

BACELLAR, Roberto Portugal. Juizados especiais: a nova mediação paraprocessual. São Paulo: RT, 2003.

BOBBIO, Norberto. Teoria do ordenamento jurídico. 10. ed. Brasília: UnB, 1999.

CAPPELLETTI, Mauro; GARTH. Bryant. Acesso à justiça. Trad. e rev. Ellen Gracie Northfleet. Porto Alegre: Fabris, 1988.

CARNELUTTI, Francesco. Como se faz um processo. 3. ed. Trad. Hebe Caletti Marenco. Sorocaba: Minelli, 2005.

CHIMENTI, Ricardo Cunha. Teoria e prática dos juizados especiais cíveis. São Paulo: Saraiva, 1999.

CINTRA, Antonio Carlos de Araújo; GRINOVER, Ada Pellegrini; DINAMARCO, Cândido Rangel. Teoria geral do processo. 20. ed. São Paulo: Malheiros, 2004.

COSTA, Fábio Silva. Tutela antecipada: hermenêutica, acesso à justiça e princípio da efetividade processual. São Paulo: Juarez de Oliveira, 2000.

CRUZ E TUCCI, José Rogério. Tempo e processo: uma análise empírica da fenomenologia processual (civil e penal). São Paulo: RT, 1997. 
Garantias constitucionais do processo civil. São Paulo: RT, 1999.

CUNHA, J.S. Fagundes. Recursos e impugnações nos Juizados Especiais Cíveis. 2. ed. Curitiba: Juruá, 1997.

DIDIER JR, Fredie. Notas sobre a garantia constitucional do acesso à justiça: o princípio do direito de ação ou da inafastabilidade do Poder Judiciário. Revista de Processo, São Paulo, n. 108, p. 23-31, out./dez. 2002.

FIGUEIRA JR, Joel Dias. Dos Juizados Especiais Cíveis. In: FIGUEIRA JR, Joel Dias; LOPES, Maurício Antônio Ribeiro. Comentários à Lei dos Juizados Especiais Cíveis e Criminais. São Paulo: RT, 1995.

FISS, Owen. Um novo processo civil: estudos norte-americanos sobre jurisdição, constituição e sociedade. São Paulo: RT, 2004.

GAJARDONI, Fernando da Fonseca. O princípio constitucional da tutela jurisdicional sem dilações indevidas e o julgamento antecipadíssimo da lide. Revista de Processo, São Paulo, n. 141, p. 150-179, nov. 2006.

HUTTER, Rudolf. Os princípios processuais no Juizado Especial Cível. São Paulo: Iglu, 2004.

MARINONI, Luiz Guilherme. Tutela antecipatória, julgamento antecipado $e$ execução imediata da sentença. 3. ed. rev. e atual. São Paulo: RT, 1999.

. Antecipação da tutela. 9. ed. rev. e ampl. São Paulo: RT, 2006.

. Curso de processo civil. São Paulo: RT, 2006. v. 1: Teoria Geral do Processo.

; ARENHART, Sérgio Cruz. Manual do processo de conhecimento. 3. ed. rev. atual. e ampl. São Paulo: RT, 2004.

NOGUEIRA, Paulo Lúcio. Juizados especiais cíveis e criminais. São Paulo: Saraiva, 1996.

SILVA, Jorge Alberto Quadros de Carvalho. Lei dos juizados especiais cíveis anotada. 2. ed. rev. atual e ampl. São Paulo: Saraiva, 2001.

SILVA, Ovídio A. Baptista da; GOMES, Fábio. Teoria geral do processo civil. 3. ed. rev. e atual. São Paulo: RT, 2002.

SOARES, Nildomar da Silveira. Juizado Especial Cível: a justiça da era moderna. 3. ed. São Paulo: LTr, 1996.

THEODORO JÚNIOR, Humberto. Boa-fé e processo: papel do juiz. In: MARINONI, Formatado: Português (Brasil) Luiz Guilherme (coord.). Estudos de direito processual civil, homenagem ao Professor Egas Dirceu Moniz de Aragão. São Paulo: RT, 2005. p. 636-647. 
Revista Eletrônica do CEJUR, Curitiba-PR, a. 2, v. 1, n. 3, ago./dez. 2008

ZENKNER, Marcelo. Ministério Público e efetividade do processo civil. São Paulo: RT, 2006.

\section{ANEXOS}

\section{ANEXO A - PROCESSOS PESQUISADOS}

\begin{tabular}{|c|c|c|}
\hline $2004.9552-8$ & $8^{\circ} \mathrm{JEC}$ & Juliana Moreira da Silva X Robson Marcel Collect \\
\hline $2005.21856-4$ & $8^{\circ} \mathrm{JEC}$ & Lucio Moreira de Bairo X Região Sul Com. de Veículos \\
\hline $2006.21787-4$ & $8^{\circ} \mathrm{JEC}$ & Solange Maria Gaviorno de Andrade X Hipermercado BIG \\
\hline $2005.29602-5$ & $8^{\circ} \mathrm{JEC}$ & Valdeci de Fátima Pinto Pozzobom X Ford Metropolitana \\
\hline $2005.21542-6$ & $8^{\circ} \mathrm{JEC}$ & Israel Antonio da Rocha X Maria Euzete Garcia Stapassol \\
\hline $2005.27337-9$ & $8^{\circ} \mathrm{JEC}$ & Marnes Alves Tavares X Farmácia e Drogaria Nissei Ltda. \\
\hline $2005.22917-1$ & $8^{\circ} \mathrm{JEC}$ & Eleonora Lenartovicz Romanovski X Unimed S/A \\
\hline $2005.31848-5$ & $8^{\circ} \mathrm{JEC}$ & Lidiane Morais de França X Cacilda P. dos Santos e outros \\
\hline $2005.31324-6$ & $8^{\circ} \mathrm{JEC}$ & Grupo Ação Prest. de Serv. Ltda X Nextel Comunicação Ltda \\
\hline $2004.7553-1$ & $8^{\circ} \mathrm{JEC}$ & Américo Zacarias X Carfer Assessoria Ltda. \\
\hline $2006.24132-8$ & $8^{\circ} \mathrm{JEC}$ & Emerson Luiz da Silva X Dist. Maringá de Eletrodomésticos \\
\hline $2003.18109-0$ & $8^{\circ} \mathrm{JEC}$ & Sandro da Silva X Mohmad Abdul Kader El Ladeki \\
\hline $2006.9769-2$ & $8^{\circ} \mathrm{JEC}$ & André Luiz Acello X Olívio Banzatto \\
\hline $2005.8606-7$ & $8^{\circ} \mathrm{JEC}$ & Gerson Lenz X Condor Super Center Ltda. \\
\hline $2005.884-8$ & $8^{\circ} \mathrm{JEC}$ & Paulo Roberto Milano X Luiz Fernando Figueiredo \\
\hline $2005.20355-3$ & $8^{\circ} \mathrm{JEC}$ & R. M. Abiko - Casa Lotérica Ltda. X Cristina Marcia Ribeiro \\
\hline $2005.30536-1$ & $8^{\circ} \mathrm{JEC}$ & Sérgio Dutra de Campos X Mecânica Capital \\
\hline 2006.10901-9 & $8^{\circ} \mathrm{JEC}$ & Orotilde de Fátima de Lara Vaz X Couto Veículos \\
\hline $2006.20470-1$ & $8^{\circ} \mathrm{JEC}$ & Alexandre Barros Neves X Aldrin Rodrigues Capanema \\
\hline $2007.2391-2$ & $8^{\circ} \mathrm{JEC}$ & Rosilene Jaquetti Baptistim X Lojas Pernambucanas \\
\hline $2006.20390-3$ & $8^{\circ} \mathrm{JEC}$ & Wellington Eduardo Bordignon X Faculdade Unibrasil \\
\hline 2006.21958-3 & $8^{\circ} \mathrm{JEC}$ & Josiane Cristine Pertel X Marcos Aurélio Rielj \\
\hline
\end{tabular}


JUIZADOS ESPECIAIS CÍVEIS ESTADUAIS: ACESSO À JUSTIÇA?

\begin{tabular}{|c|c|c|}
\hline 2007.2039-1 & $8^{\circ} \mathrm{JEC}$ & Kellen Rafagnin X Lellis Trattoria \\
\hline $2006.8550-6$ & $8^{\circ} \mathrm{JEC}$ & Marcelo Golinski da Silveira X Célia Regina F. Sfendrych \\
\hline 2004.7981-0 & $8^{\circ} \mathrm{JEC}$ & Oly Miranda Vaine X Edílson Luis Pereira Ferraz e outro \\
\hline 2006.16941-7 & $8^{\circ} \mathrm{JEC}$ & Ana Maria de Paula X Simone Afonso Padilha \\
\hline $2004.11134-5$ & $8^{\circ} \mathrm{JEC}$ & Paulo Renato Pereira X Bana Pneus \\
\hline 2006.9246-5 & $8^{\circ} \mathrm{JEC}$ & Carmelinda Marçal X Carlos Roberto da Silva \\
\hline $2005.12270-6$ & $8^{\circ} \mathrm{JEC}$ & João Luiz Netto X Banco do Brasil \\
\hline $2003.17936-8$ & $8^{\circ} \mathrm{JEC}$ & Manoel da Rosa Pereira X BV Financeira S/A \\
\hline $2005.14677-7$ & $8^{\circ} \mathrm{JEC}$ & Antonio Candido X Comércio Guararapes \\
\hline $2005.6382-9$ & $8^{\circ} \mathrm{JEC}$ & Anair Guimarães Gabardo X Marcos Moraes Menesses \\
\hline $2005.8988-8$ & $8^{\circ} \mathrm{JEC}$ & Luiz Marcelino Ribeiro X Edson Luiz Correa da Rosa \\
\hline $2006.13764-7$ & $8^{\circ} \mathrm{JEC}$ & Trillius de Siqueira Candal X Três Com. de Publicações Ltda. \\
\hline $2006.15756-8$ & $8^{\circ} \mathrm{JEC}$ & Ana Maria de Paula X Valquíria Cardoso de Lima \\
\hline $2005.34633-2$ & $8^{\circ} \mathrm{JEC}$ & Elias Fernandes da Silva X Zogbi Promovel \\
\hline $2006.10736-0$ & $8^{\circ} \mathrm{JEC}$ & Amauri Lemberg Filho X Adelmino Grofette e outro \\
\hline $2006.21230-7$ & $8^{\circ} \mathrm{JEC}$ & Jurandir Martins de Almeida X Lima - Lima Rent a Car \\
\hline $2006.21266-0$ & $8^{\circ} \mathrm{JEC}$ & Ana Paula Maciel Moreira Blaskowski X Rinaldo Moraes \\
\hline $2005.22985-4$ & $8^{\circ} \mathrm{JEC}$ & Cláudio Ferrari X Condomínio do Edifício Don Ignácio \\
\hline $2004.12180-1$ & $8^{\circ} \mathrm{JEC}$ & Elisangela Brittes X Mara Noivas Ltda. \\
\hline 2004.11914-3 & $8^{\circ} \mathrm{JEC}$ & José Adão Cordeiro X Banco Itaú S/A \\
\hline $2005.28703-8$ & $8^{\circ} \mathrm{JEC}$ & Benedita Felix de Souza X Brasil Telecom S/A \\
\hline 2007.1533-1 & $2^{\circ} \mathrm{JEC}$ & Bruna Greggio X Telet S/A \\
\hline $2006.24492-3$ & $4^{\circ} \mathrm{JEC}$ & Maria Rita Ferreira X Telet S/A \\
\hline $2005.36064-5$ & $4^{\circ} \mathrm{JEC}$ & Wagner Souza Julio X Meire Lucia Zambenedetti Ribas \\
\hline 2004.23931-6 & $5^{\circ} \mathrm{JEC}$ & Mauricio Gomes Tesserolli X Sony Ericsson e outro \\
\hline $2005.11792-2$ & $2^{\circ} \mathrm{JEC}$ & Doralia Farro X Master Card \\
\hline $2006.22502-7$ & $2^{\circ} \mathrm{JEC}$ & Gomercindo dos Santos Camarg X Georges Andreas Tsantilas \\
\hline 2006.3423-3 & $2^{\circ} \mathrm{JEC}$ & Mário Alberto Natal X Sebastião Carlos de Mello \\
\hline $2005.31561-4$ & $2^{\circ} \mathrm{JEC}$ & Maria Nogueira de Aguiar X Lojas Marisa \\
\hline
\end{tabular}


Revista Eletrônica do CEJUR, Curitiba-PR, a. 2, v. 1, n. 3, ago./dez. 2008

\begin{tabular}{|c|c|c|}
\hline $2004.5652-1$ & $3^{\circ} \mathrm{JEC}$ & Alberto Augusto Guedes Jr. X CRTUR - Clube Cat. De Turismo \\
\hline $2007.5083-2$ & $6^{\circ} \mathrm{JEC}$ & Edmarvan Cipriano Miras X Fernando Silva Rosa \\
\hline $2007.3815-1$ & $6^{\circ} \mathrm{JEC}$ & Grezielli Aparecida Ferreira Roko X Itaucard \\
\hline $2007.2425-3$ & $6^{\circ} \mathrm{JEC}$ & Adriano Knop X Santa Clara Mármores e Granitos Ltda. \\
\hline 2007.3706-2 & $6^{\circ} \mathrm{JEC}$ & Antonio de P. P. Filho e outros X Construtora Tomazi Ltda e outros \\
\hline $2007.5326-2$ & $6^{\circ} \mathrm{JEC}$ & Emanuele Cristine dos Santos X Banco Itaú S/A \\
\hline $2007.1437-9$ & $6^{\circ} \mathrm{JEC}$ & Jean Carlos Carvalho Soares X Goiânia Esporte Clube \\
\hline $2007.1417-7$ & $6^{\circ} \mathrm{JEC}$ & Mário Augusto Naba Rios X Comércio de Roupas Freitas Irene \\
\hline $2007.2261-0$ & $6^{\circ} \mathrm{JEC}$ & Wilson Rodrigues de Lara X Banco Itaú S/A e outros \\
\hline 2007.3804-9 & $6^{\circ} \mathrm{JEC}$ & Rômulo Zanini de Gouveia Pinto X Vtuning auto Peças Ltda. \\
\hline $2007.4216-2$ & $6^{\circ} \mathrm{JEC}$ & Calçados Cairo Ltda. Valdinei Ferraz de Araújo \\
\hline $2007.969-6$ & $6^{\circ} \mathrm{JEC}$ & César Augusto Barroso Serpa X Maria Lucia Torres Cardozo \\
\hline $2007.30-7$ & $6^{\circ} \mathrm{JEC}$ & Francisco Cunha Souza Filho X Bravo Diesel Ltda. e outros \\
\hline 2007.4929-9 & $6^{\circ} \mathrm{JEC}$ & Maria Lúcia Fortunato X Banco Itaú S/A \\
\hline $2007.3293-5$ & $6^{\circ} \mathrm{JEC}$ & Aristides Girardi X Robson Luiz Dumbrowski \\
\hline $2007.4716-2$ & $6^{\circ} \mathrm{JEC}$ & Fernando Fortunato Mafra X Terra Networks S/A \\
\hline 2007.1104-0 & $6^{\circ} \mathrm{JEC}$ & José Elias dos Santos X Brasil Telecom S/A \\
\hline $2006.8303-7$ & $6^{\circ} \mathrm{JEC}$ & Mauro Antonio Lutti Moscatelli X Santander Seguros S/A \\
\hline 2006.22808-8 & $6^{\circ} \mathrm{JEC}$ & Kátia Rovaris de Agostini X Pedro Soares de Lima e outro \\
\hline $2007.12985-7$ & $7^{\circ} \mathrm{JEC}$ & Éster Naddon Otoni X Brasil Telecom S/A \\
\hline $2007.2189-6$ & $7^{\circ} \mathrm{JEC}$ & Ronaldo de Almeida X Bahamas Automóveis \\
\hline 2007.1645-6 & $7^{\circ} \mathrm{JEC}$ & Flávio Knaipp x Brasil Telecom S/A \\
\hline $2007.1504-0$ & $7^{\circ} \mathrm{JEC}$ & Maria Conceição da Silva Vrigilli X Brasil Telecom S/A \\
\hline $2007.2792-4$ & $7^{\circ} \mathrm{JEC}$ & Elio Van Der Neut X Brasil Telecom S/A \\
\hline $2006.21738-1$ & $4^{\circ} \mathrm{JEC}$ & Ana Rosa Marques Chaves X Banco Itaú S/A \\
\hline 2006.18554-1 & $4^{\circ} \mathrm{JEC}$ & Marilena Celeste Buso de Souza X Luiz Fernando Peixoto e Outros \\
\hline $2007.386-2$ & $4^{\circ} \mathrm{JEC}$ & Renan Gustavo Costa Ferreira X Brasil Telecom S/A \\
\hline $2006.25477-0$ & $4^{\circ} \mathrm{JEC}$ & Norberto Brixi X Marcus Vinícius Gobbio \\
\hline $2006.25059-1$ & $4^{\circ} \mathrm{JEC}$ & Jacira de Melo X Brasil Telecom S/A \\
\hline
\end{tabular}


JUIZADOS ESPECIAIS CÍVEIS ESTADUAIS: ACESSO À JUSTIÇA?

\begin{tabular}{|c|c|c|}
\hline 2007.8736-0 & $4^{\circ} \mathrm{JEC}$ & Julienne Perozin Garofani X Três Comércio de Publicações Ltda. \\
\hline $2006.17273-2$ & $4^{\circ} \mathrm{JEC}$ & Rodrigo Palermo X C\&A Modas Ltda. \\
\hline $2006.7380-0$ & $2^{\circ} \mathrm{JEC}$ & Zilda dos Santos X Banco Santander \\
\hline $2007.12918-6$ & $2^{\circ} \mathrm{JEC}$ & José Luiz Barboza X HSBC \\
\hline $2005.31736-0$ & $2^{\circ} \mathrm{JEC}$ & Jaime Gurovski X Carolina Orminda Vieira \\
\hline $2006.21565-9$ & $2^{\circ} \mathrm{JEC}$ & Ginofram Spiacci X Della Via Pneus \\
\hline 2006.4870-1 & $2^{\circ} \mathrm{JEC}$ & Clecio Paulo Andrade X BCM Turismo e Câmbio Ltda. \\
\hline $2006.15849-2$ & $2^{\circ} \mathrm{JEC}$ & Leni Parecida Sá Silva Arruda X Estofados Karisman \\
\hline 2006.6643-2 & $8^{\circ} \mathrm{JEC}$ & $\begin{array}{l}\text { Guilherme Augusto Bittencourt Corrêa X } 14 \text { Brasil Telecom } \\
\text { Celular }\end{array}$ \\
\hline $2000.12648-9$ & $1^{\circ} \mathrm{JEC}$ & Pedro Adocial Messias X Lionel Junior de Almeida \\
\hline $2006.23702-6$ & $1^{\circ} \mathrm{JEC}$ & Sidon Keinert Junior X HDI Rannover Seguros S/A \\
\hline 2007.8098-0 & $1^{\circ} \mathrm{JEC}$ & Ivo Carniele Palmonari X HDI Ecoville Multimarcas Ltda. \\
\hline 2004.5851-0 & $1^{\circ} \mathrm{JEC}$ & Mauro Hach X Banco Itaú S/A \\
\hline 2005.4592-1 & $1^{\circ} \mathrm{JEC}$ & José Sabino da Silva X Banco Itaú S/A \\
\hline 2005.9147-1 & $1^{\circ} \mathrm{JEC}$ & João Maimoni Filho X Telet S/A \\
\hline $2005.23702-6$ & $2^{\circ} \mathrm{JEC}$ & Michelli Cristina Baldo X Lojas Renner e outros \\
\hline 2006.7198-5 & $1^{\circ} \mathrm{JEC}$ & Dinarte Antunes Netto X Renato Volpi \\
\hline $2005.24376-3$ & $2^{\circ} \mathrm{JEC}$ & Lila Jak de Lara X Telet S/A \\
\hline 2006.4712-0 & $2^{\circ} \mathrm{JEC}$ & Angela Nair Bortot Pirotelli X Lojas Renner S/A \\
\hline $2006.7827-7$ & $1^{\circ} \mathrm{JEC}$ & Fábio Roberto Nabuco Louzada X Banco Itaú S/A \\
\hline $2006.12820-7$ & $2^{\circ} \mathrm{JEC}$ & Valdemar dos Santos X HDI Rannover Seguros S/A \\
\hline 2006.20081-4 & $1^{\circ} \mathrm{JEC}$ & Dalva Inês Kielek X Ricardo Carneiro Muchailh \\
\hline
\end{tabular}

\section{ANEXO B - PRAZO ENTRE A RECLAMAÇÃO E AUDIÊNCIA DE CONCILIAÇÃO}

Prazo de 15 dias conforme a lei: 2 processos (2000.12648-9; 2006.17273-2). 


\section{Revista Eletrônica do CEJUR, Curitiba-PR, a. 2, v. 1, n. 3, ago./dez. 2008}

Prazo entre 16 e 30 dias: 2 processos (2007.2039-1; 2006.18554-1).

Prazo entre 31 e 60 dias: 20 processos (2006.7198-5; 2007.8098-0; 2004.9552-8; 2005.21542-6; 2004.7553-1; 2003.18109-0; 2004.7981-0; 2004.11134-5; 2004.12180-1; 2004.11914-3; 2006.24492-3; 2005.36064-5; 2005.11792-2; 2007.5083-2; 2007.4929-9; 2006.21738-1; 2007.386-2; 2006.25477-0; 2006.25059-1; 2007.8736-0).

Prazo entre 61 e 90 dias: 25 processos (2006.7827-7; 2004.5851-0; 2006.20081-4; 2005.9147-1; 2005.24376-3; 2005.21856-4; 2005.8606-7; 2005.14677-7; 2005.6382-9; 2005.8988-8; 2007.1533-1; 2004.23931-6; 2004.5652-1; 2007.3815-1; 2007.2425-3; 2007.3706-2; 2007.5326-2; 2007.1437-9; 2007.1417-7; 2007.2261-0; 2007.3804-9; 2007.9696; 2007.30-7; 2007.3293-5; 2007.4716-2).

Prazo entre 91 e 120 dias: 18 processos (2005.31462-6; 2006.4712-0; 2006.128207; 2006.23702-6; 2005.4592-1; 2005.22917-1; 2007.2391-2; 2005.12270-6; 2003.17936-8; 2005.22985-4; 2006.3423-3; 2005.31561-4; 2007.4216-2; 2006.8303-7; 2007.2189-6; 2005.31736-0; 2006.21565-9; 2006.15849-2).

Prazo entre 121 e 150 dias: 7 processos (2005.31848-5; 2006.9769-2; 2005.884-8; 2006.22502-7; 2006.22808-8; 2006.7380-0; 2006.4870-1).

Prazo superior a 150 dias: 22 processos (2006.6643-2; 2006.21787-4; 2005.296025; 2005.27337-9; 2005.31324-6; 2006.24132-8; 2005.20355-3; 2005.30536-1; 2006.10901-9; 2006.20470-1; 2006.20390-3; 2006.21958-3; 2006.8550-6; 2006.16941-7; 2006.9246-5; 2006.13764-7; 2006.15756-8; 2005.34633-2; 2006.10736-0; 2006.21230-7; 2006.21266-0; 2005.28703-8).

Não houve audiência de conciliação: 6 processos (2007.1104-0; 2007.12985-7; 2007.1645-6; 2007.1504-0; 2007.2792-4; 2007.12918-6).

\section{ANEXO C - PRAZO ENTRE AS AUDIÊNCIAS DE CONCILIAÇÃO E INSTRUÇÃO}

No mesmo dia: nenhum caso. 
JUIZAdOS ESPECIAIS CíVEIS ESTAdUAIS: ACESSO À JUSTIÇA?

Prazo de 15 dias conforme a lei: 1 processo (2007.2391-2).

Prazo entre 16 e 30 dias: nenhum caso.

Prazo entre 31 e 60 dias: 8 processos (2005.4592-1; 2006.24132-8; 2005.36064-5; 2007.3706-2; 2007.5326-2; 2007.969-6; 2006.22808-8; 2007.2189-6).

Prazo entre 61 e 90 dias: 11 processos (2006.6643-2; 2006.21787-4; 2005.31324-6; 2006.20470-1；2006.20390-3；2006.21958-3；2007.2039-1；2006.21230-7；2007.4929-9; 2007.386-2; 2006.17273-2).

Prazo entre 91 e 120 dias: 2 processos (2006.21738-1; 2006.21565-9).

Prazo entre 121 e 150 dias: 9 processos (2006.7827-7; 2006.20081-4; 2006.4712-0; 2005.24376-3; 2004.7553-1; 2004.7981-0; 2005.6382-9; 2006.22502-7; 2006.4870-1).

Prazo superior a 150 dias: 28 processos (2005.31462-6; 2005.9147-1; 2004.5851-0; 2006.7198-5; 2004.9552-8; 2005.21856-4; 2005.29602-5; 2005.21542-6; 2005.27337-9; 2005.8606-7; 2005.884-8; 2005.30536-1; 2004.11134-5; 2005.12270-6; 2003.17936-8; 2005.14677-7; 2005.8988-8; 2005.34633-2; 2005.22985-4; 2004.12180-1；2004.11914-3; 2005.28703-8; 2007.1533-1；2006.24492-3；2005.31561-4；2004.5652-1；2006.8303-7; 2005.31736-0).

Não houve audiência de instrução: 43 processos (2004.23931-6; 2006.25477-0; 2007.1104-0; 2007.12985-7; 2007.1645-6; 2007.1504-0; 2007.2792-4; 2007.12918-6; 2000.12648-9; 2007.8098-0; 2006.23702-6; 2006.12820-7; 2005.22917-1；2005.31848-5; 2003.18109-0; 2006.9769-2; 2005.20355-3; 2006.10901-9; 2006.8550-6; 2006.16941-7; 2006.9246-5; 2006.13764-7; 2006.15756-8; 2006.10736-0; 2006.21266-0; 2005.11792-2; 2006.3423-3; 2007.5083-2; 2007.3815-1; 2007.2425-3; 2007.1437-9; 2007.1417-7; 2007.2261-0; 2007.3804-9; 2007.4216-2; 2007.30-7; 2007.3293-5; 2007.4716-2; 2006.18554$1 ; 2006.7380-0 ; 2006.15849-2 ; 2006.25059-1 ; 2007.8736-0)$. 


\section{ANEXO D - PRAZO ENTRE A AUDIÊNCIA DE INSTRUÇÃO E A SENTENÇA}

No momento da audiência: 2 processos (2004.5851-0; 2006.22502-7).

Prazo de 10 dias: 1 processo (2005.36064-5).

Prazo entre 11 e 30 dias: 1 processo (2006.21565-9)

Prazo entre 31 e 60 dias: 8 processos (2000.12648-9; 2006.21787-4; 2006.241328;2006.21958-3; 2006.21230-7; 2007.3706-2; 2007.5326-2; 2006.4870-1).

Prazo entre 61 e 90 dias: 10 processos (2005.31324-6; 2005.30536-1; 2006.204701 ; 2007.2391-2；2006.20390-3；2004.5652-1；2007.969-6; 2007.4929-9；2006.22808-8; 2006.21738-1).

Prazo entre 91 e 120 dias: 3 processos (2006.6643-2; 2007.2039-1; 2004.7981-0).

Prazo entre 121 e 150 dias: 2 processos (2006.7198-5; 2005.21856-4).

Prazo superior a 150 dias: 22 processos (2005.4592-1; 2005.9147-1; 2006.4712-0; 2005.24376-3; 2005.29602-5; 2005.21542-6; 2005.27337-9; 2004.7553-1; 2005.8606-7; 2004.11134-5; 2005.12270-6; 2003.17936-8; 2005.14677-7; 2005.6382-9; 2005.8988-8; 2005.22985-4; 2004.12180-1；2004.11914-3；2005.28703-8; 2005.31561-4; 2006.8303-7; 2006.17273-2; 2005.31736-0).

Não houve sentença ainda: 3 processos (2005.31462-6; 2006.20081-4; 2006.78277)

Não houve audiência de instrução: 49 processos (2007.8098-0; 2006.23702-6; 2006.12820-7; 2006.8550-6; 2006.3423-3; 2006.25059-1; 2007.8736-0; 2004.9552-8; 2007.2189-6; 2007.386-2; 2005.22917-1； 2005.31848-5; 2003.18109-0； 2006.9769-2; 2005.884-8; 2005.20355-3; 2006.10901-9; 2006.16941-7; 2006.9246-5; 2006.13764-7; 2006.15756-8; 2005.34633-2; 2006.10736-0; 2006.21266-0; 2005.11792-2; 2007.5083-2; 2007.3815-1; 2007.2425-3; 2007.1437-9; 2007.1417-7; 2007.2261-0; 2007.3804-9; 2007.4216-2; 2007.30-7; 2007.3293-5; 2007.4716-2; 2006.18554-1; 2006.7380-0; 
JUIZADOS ESPECIAIS CÍvEIS ESTADUAIS: ACESSO À JUSTIÇA?

2006.15849-2; 2004.23931-6; 2006.25477-0; 2007.1104-0; 2007.12985-7; 2007.1645-6; 2007.1504-0; 2007.2792-4; 2007.12918-6; 2007.1533-1; 2006.24492-3).

\section{ANEXO E - RESULTADOS CONCILIAÇÃO/ ARBITRAGEM}

Houve conciliação: 2 processos $(2005.31848-5 ;$ 2006.18554-1).

Não houve conciliação e foi proposta arbitragem: nenhum caso.

Não houve conciliação e não foi proposta arbitragem: 63 processos (2006.128207; 2006.7827-7; 2006.20081-4; 2006.4712-0; 2005.24376-3; 2005.31462-6; 2005.9147-1; 2004.5851-0; 2006.7198-5; 2006.6643-2; 2005.4592-1; 2004.9552-8; 2005.21856-4; 2006.21787-4; 2005.29602-5; 2005.21542-6; 2005.27337-9; 2005.22917-1; 2005.31324-6; $2004.7553-1 ; \quad 2006.24132-8 ; \quad 2005.8606-7 ; \quad 2005.884-8 ; \quad 2005.30536-1 ; \quad 2006.20470-$ $1 ; 2007.2391-2 ; 2006.20390-3 ; 2006.21958-3 ; 2007.2039-1 ; 2004.7981-0 ; 2004.11134-5$; 2005.12270-6;2003.17936-8; 2005.14677-7; 2005.6382-9; 2005.8988-8; 2005.34633-2; 2006.10736-0; 2006.21230-7; 2005.22985-4; 2004.12180-1; 2005.28703-8; 2007.1533-1; 2006.24492-3; 2005.36064-5; 2004.23931-6; 2006.22502-7; 2005.31561-4; 2004.5652-1; 2007.3706-2; 2007.5326-2; 2007.969-6; 2007.4929-9; 2006.8303-7; 2006.22808-8; 2007.2189-6; 2006.21738-1; 2007.386-2; 2006.25477-0; 2006.17273-2; 2005.31736-0; 2006.21565-9; 2006.4870-1).

Houve resolução por arbitragem: nenhum caso.

Não houve audiência de conciliação: 37 processos (2006.23702-6; 2007.8098-0; 2000.12648-9; 2006.8550-6; 2004.11914-3; 2006.3423-3; 2007.1104-0; 2007.12985-7; 2007.1645-6; 2007.1504-0; 2007.2792-4; 2006.25059-1; 2007.8736-0; 2006.7380-0; 2007.12918-6; 2003.18109-0; 2006.9769-2; 2005.20355-3; 2006.10901-9; 2006.16941-7; 2006.9246-5; 2006.13764-7; 2006.15756-8; 2006.21266-0; 2005.11792-2; 2007.5083-2; 2007.3815-1; 2007.2425-3; 2007.1437-9; 2007.1417-7; 2007.2261-0; 2007.3804-9; 2007.4216-2; 2007.30-7; 2007.3293-5; 2007.4716-2; 2006.15849-2). 


\section{ANEXO F - CONDUÇÃO DAS CONCILIAÇÕES}

Conciliador: 59 processos (2006.12820-7; 2006.7827-7; 2006.20081-4; 2006.4712$0 ; 2005.24376-3 ; 2005.31462-6 ; 2005.9147-1 ; 2004.5851-0 ; 2006.7198-5 ; 2006.6643-2$; 2005.4592-1; 2005.21856-4; 2006.21787-4; 2005.21542-6; 2005.27337-9; 2005.229171;2005.31848-5; 2005.31324-6; 2004.7553-1; 2006.24132-8; 2005.8606-7; 2005.884-8; 2005.30536-1; 2006.20470-1; 2007.2391-2; 2006.20390-3; 2006.21958-3; 2007.2039-1; 2004.7981-0; 2005.12270-6; 2003.17936-8; 2005.14677-7; 2005.6382-9; 2005.8988-8; 2005.34633-2; 2006.10736-0; 2006.21230-7; 2005.22985-4; 2005.28703-8; 2007.1533-1; 2006.24492-3; 2005.36064-5; 2006.22502-7; 2005.31561-4; 2004.5652-1; 2007.3706-2; 2007.5326-2; 2007.969-6; 2007.4929-9; 2006.8303-7; 2006.22808-8; 2007.2189-6; 2006.21738-1; 2006.18554-1; 2007.386-2; 2006.17273-2; 2005.31736-0; 2006.21565-9; 2006.4870-1).

Juiz leigo: 4 processos (2004.9552-8; 2005.29602-5; 2004.11134-5; 2004.12180-1).

Juiz togado: 1 processo (2004.23931-6).

Não houve audiência de conciliação: 37 processos (2007.1104-0; 2007.12985-7; 2007.1645-6; 2007.1504-0; 2007.2792-4; 2007.12918-6; 2007.8098-0; 2000.12648-9; 2006.23702-6; 2003.18109-0; 2006.9769-2；2005.20355-3; 2006.10901-9; 2006.8550-6; 2006.16941-7; 2006.9246-5; 2006.13764-7; 2006.15756-8; 2006.21266-0; 2004.11914-3; 2005.11792-2; 2006.3423-3; 2007.5083-2; 2007.3815-1; 2007.2425-3; 2007.1437-9; 2007.1417-7; 2007.2261-0; 2007.3804-9; 2007.4216-2; 2007.30-7; 2007.3293-5; 2007.4716$2 ; 2006.25477-0 ; 2006.25059-1 ; 2007.8736-0 ; 2006.7380-0 ; 2006.15849-2)$.

\section{ANEXO G - CONDUÇÃO DAS INSTRUÇÕES}

Juiz leigo: 48 processos (2006.6643-2; 2005.4592-1; 2006.7198-5; 2005.9147-1; 2006.4712-0; 2005.24376-3; 2004.9552-8; 2005.21856-4; 2006.21787-4; 2005.29602-5; 2005.21542-6; 2005.27337-9; 2005.31324-6; 2004.7553-1; 2006.24132-8; 2005.8606-7; 2005.30536-1; 2006.20470-1; 2007.2391-2; 2006.20390-3; 2007.2039-1; 2004.7981-0; 
JUIZADOS ESPECIAIS CÍVEIS ESTADUAIS: ACESSO À JUSTIÇA?

2004.11134-5; 2005.12270-6; 2003.17936-8; 2005.14677-7; 2005.6382-9; 2005.8988-8; 2006.21230-7; 2005.22985-4; 2004.12180-1; 2004.11914-3; 2005.28703-8; 2005.36064-5; 2006.22502-7; 2005.31561-4; 2004.5652-1； 2007.3706-2; 2007.5326-2; 2007.969-6; 2007.4929-9; 2006.8303-7; 2006.22808-8; 2007.2189-6; 2006.21738-1; 2007.386-2; 2005.31736-0; 2006.21565-9).

Juiz togado: 7 processos (2006.7827-7; 2004.5851-0; 2006.20081-4; 2005.31462-6; 2006.21958-3; 2006.17273-2; 2006.4870-1).

Não houve audiência de instrução: 47 processos (2000.12648-9; 2007.8098-0; 2006.23702-6; 2006.12820-7; 2005.31848-5; 2005.22917-1;2003.18109-0; 2006.9769-2; 2005.884-8; 2005.20355-3; 2006.10901-9; 2006.8550-6; 2006.16941-7; 2006.9246-5; 2006.13764-7; 2006.15756-8; 2005.34633-2; 2006.10736-0; 2006.21266-0; 2005.11792-2; 2006.3423-3; 2007.5083-2; 2007.3815-1; 2007.2425-3; 2007.1437-9; 2007.1417-7; 2007.2261-0; 2007.3804-9; 2007.4216-2; 2007.30-7; 2007.3293-5; 2007.4716-2; 2006.185541; 2006.25477-0; 2006.25059-1; 2007.8736-0; 2006.7380-0; 2006.15849-2; 2007.1104-0; 2007.12985-7; 2007.1645-6; 2007.1504-0; 2007.2792-4; 2007.12918-6; 2004.23931-6; 2007.1533-1; 2006.24492-3).

\section{ANEXO H - SENTENÇAS}

Pareceres do Juiz leigo homologados pelo Juiz togado: 54 processos (2006.66432 ; 2005.4592-1; 2006.7198-5; 2005.9147-1; 2006.4712-0; 2005.24376-3; 2004.9552-8; 2005.21856-4; 2006.21787-4; 2005.29602-5; 2005.21542-6; 2005.27337-9; 2005.31324-6; 2004.7553-1; 2006.24132-8; 2003.18109-0； 2005.8606-7; 2006.20470-1; 2007.2391-2; 2006.20390-3; 2004.7981-0; 2004.11134-5; 2005.12270-6; 2003.17936-8; 2006.21230-7; 2005.22985-4; 2004.12180-1; 2004.11914-3; 2005.28703-8; 2005.36064-5; 2006.22502-7; 2005.31561-4; 2004.5652-1; 2007.5083-2; 2007.3815-1; 2007.2425-3; 2007.3706-2; 2007.5326-2; 2007.1437-9; 2007.1417-7; 2007.2261-0; 2007.3804-9; 2007.4216-2; 2007.9696; 2007.30-7; 2007.3293-5; 2007.4716-2; 2006.8303-7; 2006.22808-8; 2006.21738-1; 2006.25477-0; 2006.17273-2; 2005.31736-0; 2006.21565-9). 
Pareceres do Juiz leigo homologados parcialmente pelo Juiz togado: 3 processos (2005.30536-1;2007.2039-1; 2007.4929-9).

Decisões modificadas pelo Juiz togado: nenhum caso.

Sentenças proferidas pelo Juiz Togado em processos em que houve audiência de instrução: 22 processos (2000.12648-9; 2006.9769-2; 2005.884-8; 2005.20355-3; 2006.10901-9; 2006.21958-3; 2006.16941-7; 2006.9246-5; 2005.14677-7; 2005.6382-9; 2005.8988-8; 2006.13764-7; 2006.15756-8; 2005.34633-2; 2006.10736-0; 2006.21266-0; 2004.23931-6; 2005.11792-2; 2007.12985-7; 2006.7380-0; 2006.4870-1; 2006.15849-2).

Processos sem sentença ainda: 5 processos (2006.7827-7; 2006.20081-4; 2005.31462-6; 2007.1533-1; 2006.24492-3).

Acordos homologados: 4 processos (2005.31848-5; 2007.2189-6; 2006.18554-1; 2007.386-2).

Sentenças de extinção do feito sem julgamento do mérito: 8 processos (2004.5851-0; 2007.8098-0; 2006.23702-6; 2006.12820-7; 2006.8550-6; 2006.3423-3; 2006.25059-1; 2007.8736-0).

Sentenças de improcedência liminar: 6 processos (2005.22917-1; 2007.1104-0; 2007.1645-6; 2007.1504-0; 2007.2792-4; 2007.12918-6). 